OPEN ACCESS

Edited by:

Paula Jauregi,

University of Reading, United Kingdom

Reviewed by:

Guillermo Alfredo Picó,

Institute of Biotechnological and

Chemical Processes Rosario

(IPROBYQ), Argentina

Jumoke Bukola Olatujoye,

Federal University of Technology,

Nigeria

*Correspondence:

António A. Vicente

avicente@deb.uminho.pt

Specialty section:

This article was submitted to

Sustainable Food Processing,

a section of the journal

Frontiers in Sustainable Food Systems

Received: 10 May 2018

Accepted: 22 October 2018

Published: 09 November 2018

Citation:

Martins JT, Bourbon Al, Pinheiro AC,

Fasolin LH and Vicente AA (2018)

Protein-Based Structures for Food

Applications: From Macro to

Nanoscale.

Front. Sustain. Food Syst. 2:77. doi: 10.3389/fsufs.2018.00077

\section{Protein-Based Structures for Food Applications: From Macro to Nanoscale}

\author{
Joana T. Martins ${ }^{1}$, Ana I. Bourbon ${ }^{2}$, Ana C. Pinheiro ${ }^{1,3}$, Luiz H. Fasolin ${ }^{1}$ and \\ António A. Vicente ${ }^{1 *}$ \\ ${ }^{1}$ Centre of Biological Engineering, University of Minho, Braga, Portugal, ${ }^{2}$ International Iberian Nanotechnology Laboratory, \\ Braga, Portugal, ${ }^{3}$ Instituto de Biologia Experimental e Tecnológica, Avenida da República, Quinta-do-Marquês, Estação \\ Agronómica Nacional, Oeiras, Portugal
}

Novel food structures' development through handling of macroscopic and microscopic properties of bio-based materials (e.g., size, shape, and texture) is receiving a lot of attention since it allows controlling or changing structures' functionality. Proteins are among the most abundant and employed biomaterials in food technology. They are excellent candidates for creating novel food structures due to their nutritional value, biodegradability, biocompatibility, generally recognized as safe (GRAS) status and molecular characteristics. Additionally, the exploitation of proteins' gelation and aggregation properties can be used to encapsulate bioactive compounds inside their network and produce consistent delivery systems at macro-, micro-, and nanoscale. Consequently, bioactive compounds which are exposed to harsh storage and processing conditions and digestion environment may be protected and their bioavailability could be enhanced. In this review, a range of functional and structural properties of proteins which can be explored to develop macro-, micro-, and nanostructures with numerous promising food applications was discussed. Also, this review points out the relevance of scale on these structures' properties, allowing appropriate tailoring of protein-based systems such as hydrogels and micro- or nanocapsules to be used as bioactive compounds delivery systems. Finally, the behavior of these systems in the gastrointestinal tract (GIT) and the impact on bioactive compound bioavailability are thoroughly discussed.

Keywords: protein properties, oral delivery, nanotechnology, gastrointestinal tract, bioactive compound encapsulation, controlled release

\section{INTRODUCTION}

Recent strategies in food technology are centered on the development of bio-based structures for various applications such as entrapment and protection of bioactive compounds (Okuro et al., 2015; Aditya et al., 2017). Ideally, a bio-based material for food applications should be generally recognized as safe (GRAS), biodegradable, biocompatible with suitable physicochemical, and mechanical properties and not induce inflammatory reactions and toxicity, which are often associated with synthetic polymers. In addition, bio-based structures can be produced using diverse approaches, including size-reduction (e.g., nanostructures), gelation, and aggregation (Martins et al., 2015). Macro-, micro-, and nanoscale bio-based structures can be produced from proteins and polysaccharides. The design of these structures must have in consideration the essential functional features within the final food product for instance, physicochemical stability, encapsulation properties, release characteristics, and rheological properties (Jones and McClements, 2010). 
Proteins have been extensively studied due to their characteristics, i.e., dispersibility (as colloids), solubility in water, good biocompatibility, and biodegradability. Proteins' industrial applications have been known for decades. Normally, proteins are added directly to foods to improve their functionality; for example, proteins are used as an emulsifier (McClements et al., 2009; Lam and Nickerson, 2013). Also, proteins can be processed under different colloidal and physical states such as films, capsules, gels, foams, porous systems, and fibers. Therefore, numerous possibilities exist to exploit the advantageous characteristics of natural protein materials (Figure 1) (Lefèvre et al., 2014).

More recently, proteins have been studied especially as biomaterials for bioactive compounds delivery vehicles via the oral route. The idea is to transport those bioactives to the point where they need to be released (e.g., stomach and small intestine) (Matalanis et al., 2011). Usually, those bioactive compounds are especially vulnerable to food processing conditions and to digestion process (e.g., low $\mathrm{pH}$ and enzymatic reactions). This situation could lead to negative effects, mainly limiting bioactive compounds bioaccessibility and bioavailability and changing food properties (e.g., appearance, taste, and odor) (Martins et al., 2015).

A variety of proteins, from animal and vegetal origin, tends to form structures under specific conditions (e.g., temperature and $\mathrm{pH}$ ) at various state-scales, namely macro-, micro-, and nanoscale. Moreover, protein can be utilized to form diverse interactions with bioactive compounds as a result of their functional groups in the primary polypeptides' sequences. Consequently, a three-dimensional network can be created offering a range of potential binding sites for bioactive compounds, shielding them from the surroundings, and targeting them to a particular site of action (Elzoghby et al., 2012). In a scenario where healthy eating is already a priority and the consumer wants quick, easy, healthy, and ecofriendly solutions, protein-based structures have been gaining more interest for food industry due to consumer expectations.

This review article includes a brief presentation on various proteins and their potential application in the food industry. Subsequently, a detailed assessment of the literature related to the consequence of scale effect on protein properties. Moreover, we review the entrapment and/or encapsulation of bioactive compounds within protein-based structures at different dimensions. Finally, the review focuses on the performance of the protein-based structures under gastrointestinal tract (GIT) conditions.

\section{MAIN PROTEINS USED ON THE DEVELOPMENT OF PROTEIN-BASED STRUCTURES}

Proteins are large biological molecules composed of one or more amino acids' chains. These biopolymers display high nutritional value, stabilization, elasticity, as well as capacity to protect cells, tissues, and organisms. Proteins usually exist in fibrous and globular forms which are water-insoluble and are soluble in water, acids, or bases aqueous solutions, respectively (McKee and McKee, 2015). The proteins' physicochemical properties rely on the amino acid residues quantity and sequence on the polymer chain (Sağlam et al., 2014). Commonly, heat, acid, or alkaline $\mathrm{pH}$, and/or solvents are used for protein denaturation (unfolding). Once the protein is extended, chain-to-chain interaction can occur through hydrogen, ionic, hydrophobic, and covalent bonding (Gupta and Nayak, 2015).

Several functional properties are attributed to proteins, for example, water binding ability, emulsification, gelation, and foaming ability (Chen et al., 2006). Moreover, many proteinbased structures can be formed as a result of protein structural adaptability, namely coatings and films (Ramos et al., 2012), hydrogels (de Castro et al., 2017), fibers (Livney, 2015), and particles (Tarhini et al., 2017). At this point, it is important to distinguish the terms gel and hydrogel. Gels are materials composed of a three-dimensional cross linked polymer or colloidal network immersed in a fluid which are typically weak and soft; however, they can be prepared hard and tough (Saha and Bhattacharya, 2010). Hydrogels are defined as three-dimensional hydrophilic or amphiphilic networks able to swell and hold a large amount of water (Gulrez et al., 2011; Vermonden et al., 2012). Protein-based hydrogels (e.g., nanohydrogels) are a particularly interesting structure. They can be used to deliver compounds at a precise instance and location in the GIT, due to their ability to produce a response (changes in their physicochemical properties, e.g., swelling) to environmental stimulus (e.g., $\mathrm{pH}$ or temperature conditions) (Martins et al., 2015).

Currently, proteins are extensively studied and used in hydrophobic and hydrophilic bioactive compounds delivery. Proteins can be used as macro-, micro-, or nanostructures, from where bioactive compound is liberated in a controlled way to the environment (Sun et al., 2017). The design of delivery proteinbased structures should have in mind the protein surface and bulk properties. In fact, many protein-based materials used to develop controlled delivery systems center on the preparation method and on the use of environmental reactive proteins with particularly designed macro-, micro-, and nanoscopic structural and chemical attributes (McClements et al., 2009). For instance, the protein-based structure swelling or shrinking capacity when the temperature or $\mathrm{pH}$ changes, can be used to trigger bioactive compound release which could enhance the efficiency, costeffectiveness, and range of food applications (Gupta and Nayak, 2015).

Presently, many plant and animal proteins could be used as a source of material for production and design of proteinbased structures. The use of animal proteins could bring various advantages such as low toxicity of the degradation end products and high absorbability (due to the smaller nature of animal proteins) (Elzoghby et al., 2012; Can Karaca et al., 2015).

Gelatin is a protein obtained from collagen (e.g., present in bones and connective tissues of fish) by hydrolysis. Gelatin is considered as GRAS by the Food and Drug Administration (FDA) and it is used in food and pharmaceuticals products. Gelatin forms thermo-reversible hydrogels because of the formation of triple helices, guiding to chains entanglement, 


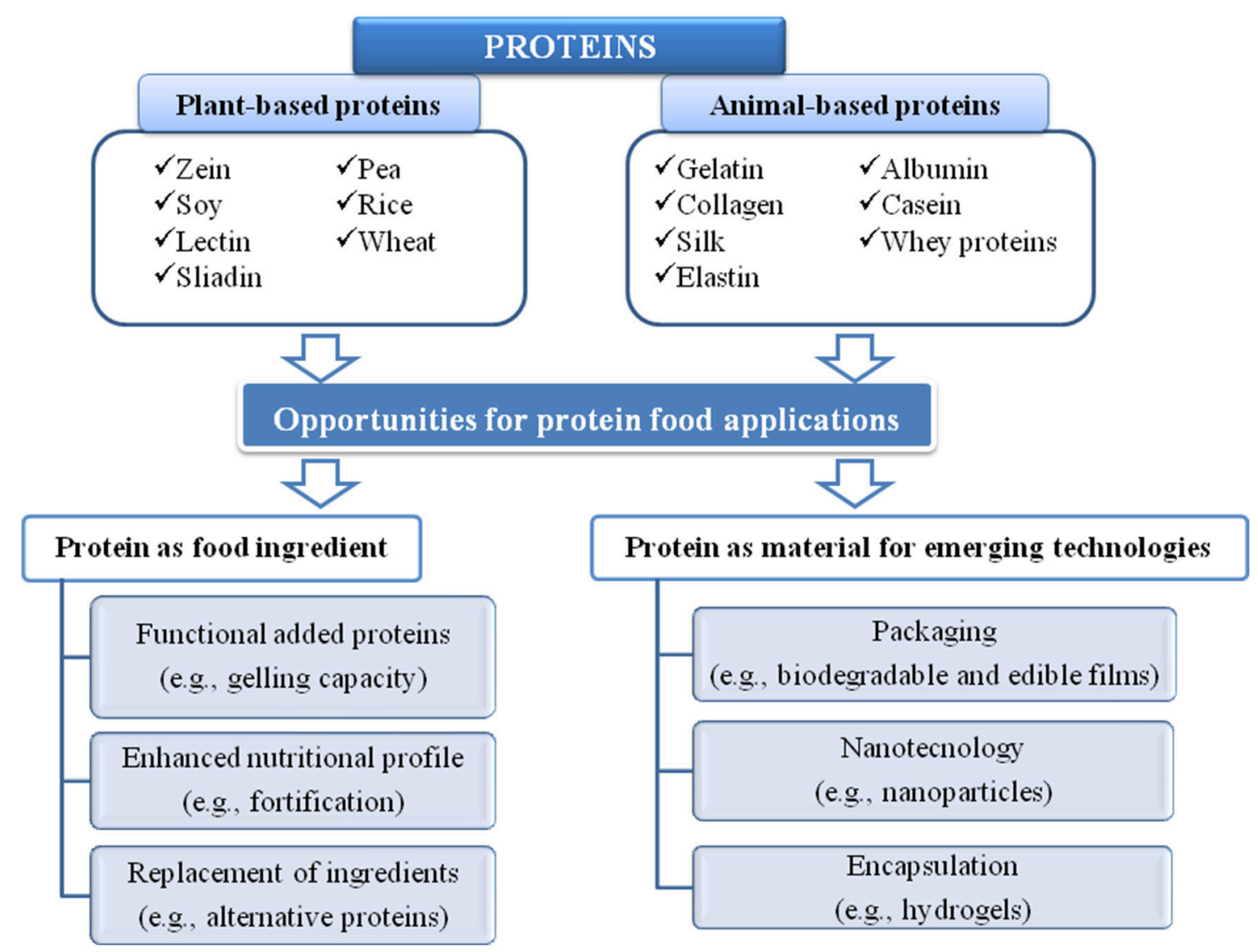

FIGURE 1 | Main plant and animal proteins used in food industry and some of their food applications.

and network formation (Elzoghby et al., 2012; GómezMascaraque et al., 2016). For instance, protein gelatin has been reported for successful delivery of bioactive compounds. Microhydrogels based on gelatin were produced to microencapsulate a flavonoid antioxidant, (-)-epigallocatechin gallate (EGCG) (Gómez-Mascaraque et al., 2016). Results demonstrated that gelatin can be used as wall material for EGCG encapsulation, achieved high encapsulation efficiency (around 95\%), successful delayed EGCG release and exhibited good EGCG bioaccessibility after in vitro GIT digestion. Also, gelatin-based films were developed with good mechanical properties. A promising study using gelatin as a biodegradable packaging material was performed (Bodini et al., 2013). The authors produced and characterized gelatin films with ethanol-propolis extract (EPE) and analyzed their antimicrobial activity. The mechanical and physical properties of gelatin films were not changed by the addition of EPE when compared to the control. Antimicrobial activity against Staphylococcus aureus was observed in films with EPE concentration higher than $5 \mathrm{~g}$ EPE/100 g gelatin.

Ovalbumin is another example of an animal protein that can be used to developing protein-based structures. Ovalbumin is the major protein found in egg white. It is a globular, acidic protein that comprises a single polypeptide chain of 386 amino acid residues with a molecular weight of $45 \mathrm{kDa}$ (Huntington and Stein, 2001; Abeyrathne et al., 2013). Moreover, ovalbumin includes hydrophobic and hydrophilic groups and acts as emulsifier, foaming agent, and gel, in food products. Ovalbumin has the potential to be a carrier for bioactive compounds in functional foods. Indeed, the study of Feng et al. (2016) on the development of ovalbumin-dextran nanogels loaded with curcumin (fabricated via the Maillard reaction and heatgelation) reported the formation of stable spherical structure (size diameter of $\approx 102.31 \mathrm{~nm}$ ) with great $\mathrm{pH}$ stability, storage stability, and redispersibility. In another study, ovalbuminlinoleic acid nanoparticles (mean diameter of $87.5 \pm 1.2 \mathrm{~nm}$ ) were obtained by heat treatment (Sponton et al., 2015). The authors stated that these nanoparticles presented good surface hydrophobicity and linoleic acid binding ability (by mean of hydrophobic interactions), which could allow the development of polyunsaturated fatty acids nanocarriers with potential food application.

Other animal proteins that are extensively study are milk proteins. They are separated into whey proteins and caseins, where $\alpha$-lactalbumin and $\beta$-lactoglobulin $(\beta$-Lg) are the main whey proteins and lactoferrin (LF) a minor whey protein. Numerous approaches have been studied for their 
use as encapsulation vehicles of bioactives due to their structural and functional variety (Livney, 2010; de Castro et al., 2017). Microparticles were produced with whey protein/sodium alginate by cold gelation (Leon et al., 2016). These particles were developed as texture modifiers and flavor carriers in food products. Results proved that protein-based particles presented good mechanical properties to prepare a soft gel that could be employed in foods that are easily masticated and swallowed (for example, food design for elderly people). More examples of animal proteins and their respective function when applied to food industry can be seen in Figure 1.

Alternatively, non-animal protein sources are gaining popularity as consumers are looking to have a diet with more plant-based alternatives and less animal-based options (Lin et al., 2017). Plant-based proteins can offer higher sustainability, lower prices, and higher safety than animal proteins (Elzoghby et al., 2012; Can Karaca et al., 2015). Indeed, there are evidences that a partial exchange of animal for vegetable proteins is related to a decreased of type 2 diabetes risk (Malik et al., 2016; Song et al., 2016). Especially, legume seeds are among the richest source of proteins and present high availability, low price, nutritional value, and positive health effects (Duranti, 2006).

Zein, a hydrophobic protein mainly found in corn kernels, is insoluble in water and soluble in alcohol solutions, which provides the potential to encapsulate lipophilic bioactive agents (Patel and Velikov, 2014). Zein (core) and $\beta$-Lg (shell) nanoparticles were used to encapsulate tangeretin, a poor watersoluble bioactive flavonoid. Thus, it could be added to aqueousbased food products as a functional ingredient (Chen et al., 2014). Also, various studies showed that zein-based film could function as a controlled release matrix for the delivery of active components, such as nisin, lysozyme, thymol, and catechin (Zhang Y. et al., 2015).

Soy protein isolates (SPI), from soybean, is also a very used protein-based material in food emulsification, bioactive compounds delivery, films, and tissue engineering (e.g., membranes) applications, due to soy protein abundance in nature, biodegradability, and low cost (Elzoghby et al., 2012). SPI-based nanoparticles were produced to improve the intestinal transport of vitamin-B12 (Zhang et al., 2014). Nanoparticles increased (2-3 times) vitamin-B12 transport through the cell layers compared to non-encapsulated vitamin-B12. Additionally, vitamin-B12 transport increased when particle size decreased from 180 to $30 \mathrm{~nm}$. Figure 1 shows more examples of vegetable proteins and their potential food applications.

Wheat is one of the major grains in the world. Wheat gliadin is a natural protein with good viscoelastic and bioadhesive properties, high tensile strength, excellent gas barrier properties, low price, and large-scale availability (Arangoa et al., 2001; Zhang et al., 2007; Lohcharoenkal et al., 2014). Several studies have been carried out on wheat protein-based structures development for oral delivery applications. Qiu et al. (2015) showed that fish oil emulsions stabilized with wheat gliadin were effective at inhibiting lipid oxidation of fish oil. Peng et al. (2018) produced wheat gliadin nanoparticles sensitive to $\mathrm{pH}$ and non-sensitive to thermal treatment. The authors stated that these properties indicated the potential application of wheat gliadin nanoparticles as a new foaming agent in food industry. In another study, gliadin and lecithin nanoparticles loaded with curcumin were fabricated by antisolvent precipitation method (Yang et al., 2018). The gliadin-lecithin nanoparticles considerably improved the encapsulation efficiency, thermal and UV light stability, and antioxidant activity of curcumin in the nanoparticles.

\section{MACRO-, MICRO-, AND NANO-SIZE EFFECT ON PROTEIN-BASED STRUCTURE PROPERTIES}

\section{Gelation Process and Structural Properties}

The ability of proteins to form gels is of major industrial relevance not only for food application but also for cosmetic, medical, and pharmaceutical applications (Clark et al., 2001; Nicolai and Durand, 2013). However, protein gel formation is a complex process that can result in different structures depending on the protein characteristics, concentration, environmental conditions, and gelation process (Speroni et al., 2010; Nishinari et al., 2014). As mentioned before, proteins are classified as fibrous [e.g., collagen (gelatin), keratin, and elastin] and globular proteins [e.g., albumins (whey and egg protein) and globulins (soy protein)]. Both types are able to form a gel; however, the gelation mechanism is different and occurs under different conditions.

Gelation usually requires a previous step with some driving force to denature native protein (i.e., unfold) followed by protein aggregation (Clark et al., 2001; de Souza Simões et al., 2017). The driving forces can be classified basically as being of a physical (e.g., heat and pressure) or chemical nature (e.g., acid, ionic strength, and enzymatic reaction) (Aguilera and Rademacher, 2004). These methods can be used alone or in combination, but changing the mechanisms of protein unfold and gelation will exert influence on their final properties (e.g., rheology, texture, microstructure, water holding capacity, and color). Also, changing the scale will modify the proteins structural arrangement and consequently, their functionality, application, and physicochemical properties.

Regarding their food application, protein gels can be produced into a large series of sizes, from bulk gels (or macrogels) to microor nanoscale particles (Sağlam et al., 2014; Nazir et al., 2016; de Souza Simões et al., 2017). Bulk gels are generally responsible to confer texture as a consequence of the biopolymer network formation during the gelation process. Numerous food products (e.g., desserts, sausages, yogurts, cheeses, and confectionery products) present a range of protein materials which gives expected sensorial and textural characteristics. The control of these characteristics depends on their structure and its relation to physical properties. Whey protein isolate (WPI), SPI, egg white, gelatin, pea, and wheat proteins, among others, have been extensively studied. Different gelation mechanisms and emerging techniques were reported to modulate the structure, functionality, and application in food systems. Some examples of systems produced with different gelation mechanisms are listed in Table 1.

Size reduction of protein-based structures could change their food application and their effects in the food products. 
TABLE 1 | Examples of protein-based structures at different sizes using different gelation approaches.

\begin{tabular}{|c|c|c|c|}
\hline Scale & Protein & Gelation technique & References \\
\hline \multirow[t]{16}{*}{ Macro } & WPI & Heat & $\begin{array}{l}\text { Zand-Rajabi and } \\
\text { Madadlou, 2016b }\end{array}$ \\
\hline & & Heat and enzymatic & Spotti et al., 2017 \\
\hline & & Acid gelation & $\begin{array}{l}\text { Queirós and } \\
\text { Lopes-da-Silva, } 2017\end{array}$ \\
\hline & & Salt-induced gelation & Kuhn et al., 2010 \\
\hline & WPI + pectin & Acid gelation & Wijaya et al., 2017 \\
\hline & WPI + caseinate & Heat & Picone et al., 2011 \\
\hline & Egg white & Heat & $\begin{array}{l}\text { Sun and Hayakawa, } \\
2002\end{array}$ \\
\hline & & $\begin{array}{l}\text { Heat and salt-induced } \\
\text { gelation }\end{array}$ & Iwashita et al., 2015 \\
\hline & & Acid gelation & Weijers et al., 2006 \\
\hline & & $\begin{array}{l}\text { Alkaline and } \\
\text { salt-induced gelation }\end{array}$ & Li et al., 2018 \\
\hline & & $\begin{array}{l}\text { Acid and salt-induced } \\
\text { gelation }\end{array}$ & $\begin{array}{l}\text { Croguennec et al., } \\
2002\end{array}$ \\
\hline & SPI & Heat & Tarone et al., 2013 \\
\hline & & Heat and high-pressure & Speroni et al., 2009 \\
\hline & & Heat and salt-induced & Chen et al., 2017a \\
\hline & & Heat and acid gelation & Chen et al., 2017b \\
\hline & & Acid gelation & Bi et al., 2013 \\
\hline \multirow[t]{13}{*}{ Micro } & WPI & Heat & Ying et al., 2013 \\
\hline & & Acid gelation & Peters et al., 2017 \\
\hline & & Salt-induced gelation & Egan et al., 2014 \\
\hline & & Heat and pressure & Suárez et al., 2016 \\
\hline & & $\begin{array}{l}\text { Heat and } \\
\text { chemical/enzymatic }\end{array}$ & Peters et al., 2015 \\
\hline & Egg white & Heat & Liu Y. et al., 2017 \\
\hline & & Heat and salt-induced & Chang et al., 2016 \\
\hline & & Heat & Chang et al., 2017 \\
\hline & & $\begin{array}{l}\text { Ultrasound and } \\
\text { chemical reaction }\end{array}$ & Zhong et al., 2015 \\
\hline & SPI & Heat and acid gelation & Chen et al., 2017b \\
\hline & & Heat and salt-induced & Chen et al., 2017a \\
\hline & & Heat & $\begin{array}{l}\text { Matsumiya and Murray, } \\
2016\end{array}$ \\
\hline & & Heat and enzymatic & Guo et al., 2016 \\
\hline \multirow[t]{10}{*}{ Nano } & WPI & Heat & Wu et al., 2015 \\
\hline & & Acid gelation & Sadeghi et al., 2014 \\
\hline & & Heat and pH-cycling & $\begin{array}{l}\text { Giroux and Britten, } \\
2011\end{array}$ \\
\hline & & Heat and ultrasound & Ma et al., 2017 \\
\hline & & $\begin{array}{l}\text { Heat and salt-induced } \\
\text { gelation }\end{array}$ & Abbasi et al., 2014 \\
\hline & Egg white & Heat & Waku et al., 2018 \\
\hline & & Heat & Sponton et al., 2017 \\
\hline & SPI & Heat and salt-induced & Zhang et al., 2012 \\
\hline & & Heat and salt-induced & Zhu et al., 2017 \\
\hline & & Heat and salt-induced & Liu and Tang, 2013 \\
\hline
\end{tabular}

WPI, whey protein isolate; SPI, soybean protein isolate.
Microparticles or microgels may be inherent to the food product due to the food material process manufacture or they may be engineered for specific purposes (Gouin, 2004; Joye and McClements, 2014; Chang et al., 2017). Microgel suspensions have been used in foods as a mean to improve food texture and mouthfeel, replace fat, and controlled delivery of compounds (Lucca and Tepper, 1994; Chang et al., 2017). In the same way as the macrogels, protein-based microgels can be produced through different gelation mechanisms (Table 1).

Contrary to microgels, the expansion of nanotechnology and development of nanogels for food applications can be considered recent. Much has been done in this area, using different sources of protein, such as milk proteins (e.g., whey protein, casein, $\mathrm{LF}$, and $\beta-\mathrm{Lg}$ ), soy proteins, gelatin, etc. The main target of these structures is nano-encapsulation since food manufacturers seek advanced technologies to transport bioactives (e.g., vitamins and minerals) that usually present a negative effect on food texture, flavor, and mouthfeel. However, another key driver to nanostructures application has been their interfacial performance for the oil-water and air-liquid interfaces stabilization which are important for emulsified and foamed products, respectively (Liu F. et al., 2017; Zhu et al., 2017). Recent advances in nanogels production and encapsulation using proteins are also listed in Table 1.

\section{Rheological and Textural Properties}

Rheological properties of protein gels rely on the materials' microstructure and are an essential parameter to evaluate processing conditions, structure, stability, and sensorial properties. It is not only the building blocks arrangement of the structure that is important but also the conditions under which this structure is submitted (Steffe, 1996). Through its lifetime (i.e., processing, shelf-life, and consumption), the food product will be submitted to different processes that involve different shear rates. Some process steps have high shear rates and different temperatures, such as agitation, piping, and heat exchange. During its shelf-life, the food product is at rest or low shear rates are applied. Also, during food consumption, the food is subjected to a complex set of forces (i.e., mastication and swallowing) which will confer to the consumer the sensorial and palatability attributes (Kuhn et al., 2012). In addition, through the GIT, the food properties will also change, improving, or worsening the absorption process (Dekkers et al., 2016; Wu et al., 2016). Thus, the determination of the protein-based structure rheological properties is essential for understanding the behavior of the food during their whole life cycle.

Considering that rheological properties are sensitive to the applied shear rates, diverse rheological measurements can be conducted to evaluate the protein gel's behavior under small and large deformations. In short, small deformations are evaluated in small-amplitude oscillatory shear tests (within the linear viscoelastic region, Steffe, 1996). These measurements are a great tool to developing new products because they allow to understand microstructure changes during gel formation and to assess network properties. When deformation increases, stress and strain relation is non-linear and the rheological behavior is difficult to estimate. At last, when the product does not support 
the forces applied, gel fracture occurs which can be evaluated through failure tests (Kuhn et al., 2012). However, the physical properties and the rheological measurements performed for a specific product can be more or less relevant depending on the material size.

Macro or bulk protein gels are generally evaluated according to their sol-gel transition, thermo-reversibility, and gel strength (Fazani Cavallieri et al., 2010; Picone et al., 2011; Tarone et al., 2013; Chen et al., 2017a; Queirós and Lopes-da-Silva, 2017). The sol-gel transition is used to determine the gelling temperature at specific conditions being useful not only to produce macrogels but also to use this information in the top-down particles production. However, the gel point is not consensual and many criteria have been presented over the years, being perhaps the crossover between elastic $\left(G^{\prime}\right)$ and viscous $\left(G^{\prime \prime}\right)$ modules the most adopted. Gels can be also classified as weak or strong gels through the analysis of the $G^{\prime}$ and $G^{\prime \prime}$ as a function of frequency. Typically, mechanical spectra of gels show a great predominance of $G^{\prime}$ in relation to $G^{\prime \prime}$. Moreover, $G^{\prime}$ presents relatively frequency independence over a wide frequency range (Chen et al., 2017a; Queirós and Lopes-da-Silva, 2017).

Hydrogels prepared from animal and vegetable protein sources, such as whey, soy, gelatin, egg white, and wheat proteins were previously discussed in detail in the literature, as well as their physical and rheological properties. Therefore, the main characteristics of some protein gels are briefly discussed below.

WPI gels can be formed above denaturation temperature (above $75^{\circ} \mathrm{C}$ ) and at a critical protein concentration. WPI under heat and acidic conditions forms translucent, fine-stranded gels with a dense and regular microstructure. Also, a more heterogeneous microstructure with a particulate gel structure is formed close to the isoelectric point (pI) (Boye et al., 1995, 1997). Protein concentration increase could conduct to an improve of gel hardness (Boye et al., 1995; Bryant and McClements, 2000). WPI gels can also be induced by extrinsic factors that can modulate their microstructure, water holding capacity, rheological, and textural properties. The use of different salts (e.g., $\mathrm{NaCl}$ and $\mathrm{CaCl}_{2}$ ) (Bryant and McClements, 2000; Kuhn et al., 2010), acidification (e.g., organic acids, glucono- $\delta$-lactone, and $\mathrm{HCl}$ ) (Picone et al., 2011; Queirós and Lopes-da-Silva, 2017; Wijaya et al., 2017), and enzymes (Spotti et al., 2017) were reported.

Egg white proteins contain high concentration of various soluble proteins and they are able to form gels induced by heat (Campbell et al., 2003; Raikos et al., 2007; Medina-Torres et al., 2010). The egg white gels quality is influenced by environmental conditions (e.g., pH and ionic strength) (Campbell et al., 2003; Aguilera and Rademacher, 2004). However, these gels are not utilized to form complex materials since they present weak mechanical strength. Indeed, the addition of salts or $\mathrm{pH}$ values around their pI led to weak gels, but their strength can be enhanced at alkaline conditions (Croguennec et al., 2002). Still, new alternatives and processes have been explored recently in order to enhance gel mechanical strength and applicability. Use of salt and sugars combination, Maillard reaction and surfactants are examples of the modification applied to this protein (Campbell et al., 2003; Raikos et al., 2007; Iwashita et al., 2015; Li et al., 2018; Nojima and Iyoda, 2018).

Among the vegetable sources of protein, SPI is the most studied one. This biopolymer comprises two main fractions: glycinin (or 11S globulin) and $\beta$-conglycinin (or 7S globulin). SPI has been known to form stable networks in the presence of other ionic compounds and in different $\mathrm{pH}$ solutions. Under similar conditions, glycinin form harder gels with higher $G^{\prime}$-values compared to $\beta$-conglycinin (Renkema et al., 2001; Tarone et al., 2013). On the other hand, mixtures of both fractions present higher gelling capacity than the individual fractions, indicating possible interactions between them (Renkema et al., 2001). Also, SPI gels are formed through salt addition or acidification (Maltais et al., 2005, 2008). However, the gelling potential of this protein has not been fully exploited. Recently, researchers evaluated the effect of salts and $\mathrm{pH}$ on thermal aggregation and gelling ability (Chen et al., 2017a,b). They showed that the influence of decreasing $\mathrm{pH}$ and increasing $\mathrm{NaCl}$ concentration was similar, leading to a quicker gelation, and aggregation but did not exert an influence on the gel stiffness.

Gelatin has a different gelation mechanism since it is not a globular protein. Despite of this, it is the most studied biopolymer used in food industry for different purposes. It is a collagenderived water-soluble biomacromolecule and its classified into type-A or type-B according to its production process (Sundar et al., 2010). The gelation mechanism is similar to the one observed for polysaccharides: helix-coil transition at higher temperatures and a cross-link via a disorder-to-order transition with a temperature decrease (Babin and Dickinson, 2001). The extraction conditions will exert influence on the network strength, as well as gelatin concentration, $\mathrm{pH}$, temperature, salts presence, and sample time history (Babin and Dickinson, 2001; Aguilera and Rademacher, 2004). Chemical and physical crosslinking and synergistic gelation were also described and different alternatives to enhance gelatin hydrogel properties have been evaluated (Hellio and Djabourov, 2006; Maki et al., 2014; Baigts Allende and De Jongh, 2015; Wang et al., 2017).

When the particle size is reduced, the evaluation of the rheological properties usually occurs in how they exert an effect in the system where they are incorporated. Such effect is not only related to the properties of the particles, but also to their concentration. Theoretically, the effect of particles addition on the viscosity of solutions can be evaluated using Einstein's equation to high diluted systems. This equation relates the properties of the continuous medium and the phase volume fraction of a hard sphere. Although they are not hard spheres, protein microgels enclose solvent and they present rheological characteristics between that of polymer molecules and hard spheres (Stokes, 2011). Microgels phase volume is not evident because they are swollen by the solvent. However, the dilute suspensions' viscosity is linked to the occupied microgel volume according to the Einstein's equation (Adams et al., 2004). When concentration increases, the microgels can influence each other and Einstein's equation is not suitable. Several structure models were developed to explain the viscosity as a function of phase volume and concentration increase. However, most of the properties are determined empirically (Adams et al., 
2004; Stokes, 2011). Generally, an increase in volume fraction of microparticles increases the shear-thinning behavior and the suspension viscosity (Perrechil et al., 2011).

Recently, an emerging technique called microrheology has attracted attention and has been used to investigate the rheological and dynamics properties of micro- and nanosized soft matters. This technique is divided into passive and active microrheology, depending on the forces exerted on the particles. In passive microrheology, tracer particles are scattered under thermal fluctuations and their linear viscoelasticity is evaluated. On the other hand, in active microrheology, tracers are manipulated by external forces. Despite several advantages over traditional rheology, it is very difficult to establish a correlation with bulk measurements, especially for complex systems. Recent comprehensive reviews describe in detail the fundaments of microrheology, advantages, challenges, and their application in food science (Moschakis, 2013; Yang et al., 2017).

However, the great majority of research works evaluate the microparticles addition effect on the bulk rheology and texture properties of the final product due to analytical simplicity and widely disseminated techniques. Protein microparticles were applied in different food models such as emulsions, yogurts, fruit juice, bread, among others (Torres et al., 2011; Ying et al., 2013; Chung et al., 2014; Chang et al., 2016, 2017). Additionally, the smaller the structure size, the lower the effect on product properties, which means that higher micro-sized protein-based structures concentrations will be needed to exert some rheological effect. In the case of nano-sized protein-based particles, it is interesting to observe that their physicochemical properties differ from the bulk. However, their presence does not change the rheological and sensory properties of the food product being imperceptible in the mouth (Livney, 2015).

\section{Functional Properties}

One of the most relevant properties of protein's selection is their functionality. Numerous studies are being performed in order to improve the knowledge of proteins functionality in order to keep the advantage of their use in different applications (e.g., food, pharmaceutical, and cosmetic products) (Kinsella, 1979; Jones and McClements, 2011). Their functional properties include solubility, gelling ability, emulsification, foaming formation and are dependent of their intrinsic properties (such as molecular size, charge distribution, and three-dimensional structure) and extrinsic factors (such as temperature, ionic strength, and $\mathrm{pH}$ ). The proteins' function-structure associations determine their interactions with themselves and with other ingredients in complex environments (e.g., food systems) (Wong et al., 1996; Graveland-Bikker and de Kruif, 2006).

The design of a protein structure at different scales (i.e., macro-, micro-, or nanoscale) involves the understanding of the functional property that is required for the final application of this structure. The scale effect on proteins functionality can be a relevant factor interfering with the sensory properties of products, i.e., texture (e.g., solutions, gels, foams, emulsions, and extruded pieces), color (e.g., browning reactions), and flavor (e.g., via browning reactions and by entrapment or binding of both desirable and undesirable flavors) (Kinsella and Melachouris,
1976). Furthermore, in the case of food products, some of the organoleptic properties can be controlled by the size of the structure, interfering with the appearance of the final product. Microstructures with a size ranging between 0.01 and $0.1 \mu \mathrm{m}$ can promote a viscous and empty texture on the product, while particles with size around $1-2 \mu \mathrm{m}$ have a creamy effect. On the other hand, higher particle size (around 8-10 $\mu \mathrm{m}$ ) have a gritty texture effect (Damodaran, 1997).

The selection of nanoscale for protein structures (e.g., nanohydrogels) is usually required to improve the stability or bioaccessibility of bioactive compounds and minimize their influence on color, texture, and flavor of the final product. Moreover, these protein-based nanostructures are usually used to enhance the food product nutritional value without affecting sensory properties. For example, in order to reduce the fat or salt content, or for removal of certain additives in the food products, protein-based systems at the nano- and microscale (emulsions) have been used to maintain their stability (Neethirajan and Jayas, 2011). This promoted the formation of novel taste and textures, and the development of foods with low calories and with high nutritional value for diverse health conditions and lifestyles. Table 2 reports some examples of the influence of systems scale on proteins' functional properties.

Moreover, various research works have also reported the ability that the same materials with different scales (from nanoto microscale) have on packaging properties such as a barrier to moisture, mechanical properties, and as a vehicle to deliver active compounds (Neethirajan and Jayas, 2011; Schmid et al., 2012). The use of nanolayers is also an advantage in economic terms, once it only requires a few amounts of a biopolymer such as proteins to improve the stability of bio-based structures at different environmental conditions (e.g., GIT environment and food matrices) (McClements and Rao, 2011). The application of nanolayers on emulsion structures to improve mucous adhesion and to control the compound delivery at the specific target location is an example of relevant properties at the nanoscale.

\section{BIOACTIVE COMPOUNDS ENTRAPMENT/ENCAPSULATION ON PROTEIN-BASED STRUCTURES}

\section{Macro- and Microscale Structures}

Protein-based structures are undoubtedly one of the most commonly used matrices in food applications. Some of the reasons for their widespread application are their amphiphilicity (i.e., their ability to bind to lipophilic and hydrophilic compounds), high stability, and no toxicity. The delivery systems effectiveness is extremely important for improving bioactive compound bioavailability and their ability to cross biological membranes. In order to answer these challenges, protein-based structures (e.g., hydrogels) are being developed at macro- $(\geq 1,000 \mu \mathrm{m})$ and microscale $(0.1-1,000 \mu \mathrm{m})$ and used to encapsulate, protect, and release bioactive compounds to a specific target. The design of a structure, namely its size, is highly important once it was observed that micro- and nanoscale structures are favorable for encapsulation properties 
TABLE 2 | Influence of nano-, micro-, and macroscale on protein functional properties.

\begin{tabular}{|c|c|c|c|}
\hline Functional property & Nanoscale influence & Micro- and macroscale influence & References \\
\hline Gelation & $\begin{array}{l}\text { High storage moduli at low concentrations: less } \\
\text { protein material needed; } \\
\text { Transparent gels }\end{array}$ & $\begin{array}{l}\text { Rigid structure; } \\
\text { Low transparency; } \\
\text { Higher protein concentration }\end{array}$ & $\begin{array}{l}\text { Graveland-Bikker and de Kruif, 2006; He } \\
\text { and Hwang, } 2016\end{array}$ \\
\hline Emulsification & $\begin{array}{l}\text { No effect on the sensorial properties of food } \\
\text { products }\end{array}$ & $\begin{array}{l}\text { High creaming rate; } \\
\text { Lower physical stability }\end{array}$ & $\begin{array}{l}\text { Jouenne and Crouzet, 2000; Zuidam and } \\
\text { Shimoni, 2010; Dickinson, 2012, } 2015\end{array}$ \\
\hline Permeability enhancer & High permeability in contact with cells & High water-holding capacity & $\begin{array}{l}\text { Verheul and Roefs, 1998; Cooksey et al., } \\
\text { 1999; Sobral et al., 2001; Rhim et al., } \\
\text { 2007; Neethirajan and Jayas, 2011; } \\
\text { Adamczak et al., } 2016\end{array}$ \\
\hline Viscosity & Low effect on viscosity & $\begin{array}{l}\text { Promote the development of } \\
\text { semi-solid behavior }\end{array}$ & $\begin{array}{l}\text { Akkermans et al., 2007; Bokkhim et al., } \\
\text { 2013; Muschiolik and Dickinson, } 2017\end{array}$ \\
\hline Solubility & $\begin{array}{l}\text { Improved solubility, targetability, and adhesion } \\
\text { to tissues }\end{array}$ & Lower solubility & $\begin{array}{l}\text { Sava et al., 2005; Saluja and Kalonia, } \\
\text { 2008; Zimet and Livney, 2009; Kayitmazer } \\
\text { et al., 2013; Khare and Vasisht, 2014; } \\
\text { Mirafzali et al., 2014; Davidov-Pardo et al., } \\
\text { 2015; Sharif et al., } 2017\end{array}$ \\
\hline Encapsulating agent & $\begin{array}{l}\text { High surface area; } \\
\text { Improve the controlled release }\end{array}$ & $\begin{array}{l}\text { Manipulation of encapsulating } \\
\text { environment difficult/impossible }\end{array}$ & $\begin{array}{l}\text { Akkermans et al., 2007; Tárrega and } \\
\text { Costell, } 2007 \text {; Doherty et al., 2011; Ngan } \\
\text { et al., } 2014\end{array}$ \\
\hline
\end{tabular}

at sub-cellular level. For instance, the mechanical flexibility of microgels allows cellular uptake modulation and improves biodistribution (Jiang et al., 2014). Also, protein microstructures can be used in food applications by carrying, protecting sensitive functional compounds, and controlling their rate release; disguising unpleasant aromas and flavors and increasing satiety (Chen et al., 2006; Li et al., 2013). In fact, although protein hydrogels (i.e., macroscale) are the most widely used structure for food applications, it is necessary to decrease size structure to allow its inclusion in non-solid food products without disturbing their sensory attributes (Chen et al., 2006).

Protein-based structures at macroscopic dimensions, for instance bulky gels and hydrogels, induce more awareness in the last years due to the opportunity of using these macrostructures as delivery matrices allied to the texture that such structures confer to food. Although the focus on the encapsulation field is in the micro- and nanoscale, considerable research has been done with macroscale (e.g., hydrogel). The researchers generally evaluate the macrostructure ability to load an bioactive agent, the effect on the macrostructure and bioactive compound release profile in some specific medium conditions (e.g., specific $\mathrm{pH}$ and temperature conditions) or in GIT (Gunasekaran et al., 2006; Zand-Rajabi and Madadlou, 2016a,b; Ozel et al., 2017). For example, bulk hydrogels showed promising applications for certain delivery routes, such as implantable drugs depots, topical application, and oral administration. Indeed, these application areas present the highest number of publications related to the evaluation of the release profile of bioactive compounds from protein-based macrostructures.

However, one of the main limitations of using macroscale protein-based structures is the restricted access to regions of the body where it is only possible to reach using small dimension structures (namely micro- and nanoscale). Furthermore, macrostructures have lower surface:volume ratio, limiting bioactive compounds' diffusion. Thus, in general, protein macro-structures can be used to protect the bioactive compound through the GIT, preserving its bioaccessibility which does not necessarily mean greater bioavailability. These limitations could be resolved by decreasing size structure to micro- or nano-scale.

Numerous proteins are used to form gels under specific conditions at microscale allowing the encapsulation of active molecules and their release. Pepe et al. (2017) developed gelatin microgels by microfluidic with high sensitive response to $\mathrm{pH}$ and ionic strength, controlling their swelling and uptake behavior. These authors used two model compounds (rhodamine B and methylene blue) to analyse the uptake and release mechanism at specific conditions, mimetizing the stomach environment (Pepe et al., 2017). These microgels can be a useful tool for tissue engineering. In addition, Anaya Castro et al. (2018) produced SPI and acylated soy protein microparticles by spraydrying to encapsulate and release ibuprofen (a poorly soluble drug model). These authors obtained high microencapsulation efficiencies, confirming the excellent properties of these proteins to encapsulate and be used as $\mathrm{pH}$-sensitive delivery systems for the oral route (Anaya Castro et al., 2018).

Milk proteins such as whey protein concentrate (WPC) are usually used to encapsulate essential oils in order to reduce their oxidation and improve their stability and solubility in aqueous medium. Baranauskiene et al. (2006) developed WPCbased microparticles (sizes around $2-556 \mu \mathrm{m}$ ) to encapsulate natural flavors such as oregano essential oil, citronella extract and sweet marjoram by spray-drying. Another work reported the use of whey protein microcapsules to encapsulate Bifidobacterium breve $R 070$ and Bifidobacterium longum R023. These work concluded that bifidobacteria immobilization in whey protein microcapsules enhanced their tolerance to acid environment. Therefore, these microcapsules are a feasible approach to delivery bifidobacteria to the human GIT (Picot and Lacroix, 2004). 
Nevertheless, it is important to highlight that microstructures are unlikely to cross most biological barriers and entering cells, and transport bioactive compounds within directly to the site of interest. Therefore, a scale reduction of protein-based structures from micro- to nano-scale could be a strategy to increase the structures capacity to cross such barriers.

\section{Nanoscale Structures}

Due to their small sizes, protein-based nanostructures (one to several hundred nanometers) are promising systems to encapsulate and deliver bioactive compounds. Nanoencapsulation protects the bioactive compounds against degradation during production and shelf-life and in particular, their small sizes can have a positive effect in improving the bioavailability of bioactive compounds with poor absorption rates and on the minimization of adverse effects on sensorial characteristics (Zimet and Livney, 2009). Protein basednanostructures can also be a valuable strategy to improve the solubility and chemical stability of poorly soluble bioactive compounds (Sponton et al., 2017).

Therefore, different works can be found in the literature reporting the benefits of encapsulating different bioactive compounds in a wide range of protein-based nanostructures namely nanoparticles, nanohydrogels and nanofibers.

Among all proteins, whey proteins have been intensively studied as nanovehicles for bioactive compounds. For example, EGCG has been encapsulated with good loading efficiency $(60-70 \%)$ in heat-denatured $\beta$-Lg nanoparticles $(<50 \mathrm{~nm})$. The authors observed that the nanoentrapment inhibited the bitterness and astringency of EGCG (Shpigelman et al., 2012). In another study, $\beta$-Lg nanoparticles $(142 \mathrm{~nm}$ ) encapsulating curcumin presented $>96 \%$ encapsulation efficiency. Also, curcumin solubility in $\beta$-Lg nanoparticles was considerably improved to $\approx 625 \mu \mathrm{M}$, being its aqueous solubility $30 \mathrm{nM}$ (Sneharani et al., 2010). Moreover, it was observed that curcumin bound to $\beta$-Lg stability was higher ( $\approx 6.7$ times) in comparison to curcumin alone. The curcumin solubility was also enhanced by four decades when encapsulated in casein nanoparticles (due to the inhibition of curcumin crystallinity), which increased their biological activity (Pan et al., 2013). Other authors developed LF nanoparticles by thermal gelation for iron delivery. The nanoparticles showed an ironbinding efficiency value of $\approx 20 \%$ and showed to be stable to temperature $\left(4-60^{\circ} \mathrm{C}\right)$ and $\mathrm{pH}(\mathrm{pH} 2-11)$ variations and during shelf-life (76 days at $4^{\circ} \mathrm{C}$ ). Results from iron release experiments showed a $\mathrm{pH}$-dependent behavior (Martins et al., 2016).

As previously stated, plant proteins have been used in the production of nanoparticles. An example is SPI that has been recently used to encapsulate resveratrol. These nanoparticles $(\approx 100 \mathrm{~nm})$ were produced using a simple rotary evaporation technique. They exhibited more than two times higher solubility compared to free resveratrol, while encapsulated resveratrol showed to be stable and remained bioactive (Pujara et al., 2017). Other authors produced barley protein nanoparticles (90$150 \mathrm{~nm}$ ) using only high-pressure homogenization (i.e., without surfactants or organic solvents). The nanoparticles demonstrated high $\beta$-carotene loading capacity (50\%) and excellent stability (Yang et al., 2014).

The use of egg white protein has been also recently explored to produce a nanovehicle for linoleic acid delivery. It was observed that the particle size decreased and linoleic acid binding capacity increase when $\mathrm{pH}$ increased, being the latter explained based on the increased egg white protein surface/volume ratio (Sponton et al., 2017). In a subsequent work, the authors showed that, in general, the particle size distribution and the linoleic acid binding capacity of the egg white protein nanovehicles did not change after spray drying (Sponton et al., 2018).

Nanohydrogels have been extensively used in the last years to encapsulate both hydrophilic and lipophilic bioactive compounds. Caffeine and curcumin (i.e., hydrophilic and lipophilic compound, respectively) were efficiently encapsulated in LF-glycomacropeptide (LF-GMP) nanohydrogels with high encapsulation efficiencies ( $>90 \%$ ) by thermal gelation (Bourbon et al., 2016a). The authors investigated the release mechanisms of these bioactive compounds at different $\mathrm{pH}$ and observed a $\mathrm{pH}$-dependent release profile. Results showed that relaxation was the leading event for both compounds at $\mathrm{pH} 2$, whereas Fick's diffusion was the major caffeine release mechanism at $\mathrm{pH}$ 7. However, curcumin was not released from nanohydrogels at $\mathrm{pH} 7$.

Also, nanofibers composed of proteins have been studied as possible nano-based vehicles for bioactive compounds. For example, galic acid was successfully encapsulated into zein nanofibers developed using electrospinning. It was shown that the antioxidant activity of gallic acid was kept after inclusion in the zein electrospun nanofibers (Neo et al., 2013).

However, protein-based nanostructures also present some limitations, such as the fact of usually being highly unstable to aggregation due to their relatively high surface hydrophobicity. This limitation can be overcome through a layer of emulsifier molecules to stabilize them, as it was shown with the zein particles stabilization using sodium caseinate (Patel et al., 2010). Moreover, undesirable burst release phenomenon is commonly encountered in protein-based nanostructures. It has been shown that the high burst release of nanohydrogels can be reduced or minimized by coating the nanohydrogels with increasing number of polyelectrolyte layers. In fact, the layer-by-layer (LbL) approach can be used to alter the permeability and swelling behavior of nanohydrogels (Tan et al., 2008).

As shown, the majority of the earlier work on protein basednanoparticles focused on the development of a single type of nanostructure for bioactive compounds encapsulation. However, the development of nanoparticle delivery systems containing more than one type of nanoparticles with diverse functional features may bring interesting advantages (McClements, 2017). For example, labile hydrophobic bioactive compounds can benefit from encapsulation within protein-based nanoparticles (designed to protect them from chemical degradation), which are then mixed with lipid nanoparticles to offer a basis of digestible triglycerides, increasing bioactive compound solubility in GIT fluids. 


\section{BEHAVIOR OF PROTEINS-BASED STRUCTURES UNDER GIT CONDITIONS}

\section{Digestion}

The effectiveness of a bioactive compound depends on the preservation of its bioavailability, which represents a major challenge because only a small proportion of the molecule remains available after ingestion, limiting its bioactivity, and potential health benefits. This fact is related to low solubility in GIT fluids, inadequate residence time and instability under GIT conditions (Chen et al., 2006). Actually, during their passage through the different regions of the human GIT, protein-based structures experience a sequence of physiological and physicochemical processes, before the release of bioactive compounds.

Early in the oral phase, protein-based structures suffer dilution once mixed with saliva and are submitted to a complex forces/flow profile. Also, protein-based structures' $\mathrm{pH}$, temperature, and ionic strength can change and be broken down by chewing into smaller portions.

However, protein-based structures face the harshest physiological and physicochemical conditions within the stomach that may additional change their structure and composition: (i) high acidity (i.e., pH between 1 and 3) that may cause the degradation of some proteins; (ii) the presence of gastric proteases that begin protein digestion, resulting in a peptides and amino acids mixture; (iii) high ionic strength, that together with the $\mathrm{pH}$ variation, may lead to changes in the electrical characteristics of ionisable groups, and consequently, to changes in the integrity, permeability, or aggregation of structure, and (iv) complex flow/force patterns (i.e., gastric motility) that break down any remaining large fragments.

In the small intestine, protein-based structures are mixed with small intestine fluids that consist of: (i) sodium bicarbonate which increases the $\mathrm{pH}$ from highly acidic to closer to neutral; (ii) bile salts and phospholipids that facilitate lipids' emulsification; (iii) pancreatic enzymes involved in digestion of proteins (trypsin and chymotrypsin), lipids (lipase), and starch (pancreatic amylase); (iv) different salts that increase the ionic strength of the medium, and (v) co-lipase, important to achieve the optimum lipase activity. The small intestine is the main site for bioactive compounds solubilization, transport and absorption (Gonçalves et al., 2018).

The colon is only reached by a compounds' fraction not digested nor absorbed in the upper GIT (i.e., indigestible compounds such as dietary fibers). Therefore, protein-based structures are not expected to reach the colon (McClements, 2014).

Regarding the release mechanisms occurring throughout digestion, they will depend on the bioactive compound characteristics: hydrophilic compounds are released from a protein structure by diffusion (Chen and Subirade, 2009), whereas lipophilic compounds are mainly released by protein structure enzymatic degradation in the GIT (Wang et al., 2011).

It is known that hydrogel particles may be planned to control the release of a bioactive component on a specific location (i.e., mouth, stomach, small intestine, or colon) within the GIT. This can be accomplished by the careful selection of the protein building blocks and the forces holding them together. Also, they can control the release kinetics (e.g., burst or sustained release profiles) of encapsulated bioactive components within the GIT. Bioactive components' release behavior will depend on protein particles' composition, size, structure, and environmental responsiveness (Zhang Z. et al., 2015).

Different studies can be found in the literature regarding the evaluation of protein-based structures under both in vitro and in vivo GIT conditions in order to study their behavior, in addition to the bioactive compounds' bioaccessibility, when submitted to the digestion conditions. Some examples of protein-based structures at different scales (macro, micro, and nano) under GIT conditions can be found in Table 3.

As can be seen in Table 3, a wide range of advantages can be obtained from the encapsulation of different bioactive compounds in protein-based structures regarding their stability and bioaccessibility under GIT conditions. However, one of the main limitations of protein-based structures (especially, if produced by physical gelation) is their susceptibility to be disrupted under physiological conditions in the GIT, preventing the delivery of the encapsulated compound at a specific target. In order to preserve their functionality, they must be designed to resist the harsh gastric environment (enzymes and low pH). This could be circumvented by carefully selecting the protein to produce the delivery structure. For example, $\beta$-Lg is identified to be very resistant to stomach enzymatic degradation and stable at low $\mathrm{pH}$. This feature has been shown in different works. For example, $\beta$-Lg nanostructures loaded with riboflavin proved to be stable within the stomach, but they were degraded in the duodenum. Moreover, $11 \%$ riboflavin was release in the stomach, whereas 35,38 , and $5 \%$ riboflavin was released in the duodenum, jejunum and ileum, respectively. The authors conclude that $\beta$ Lg nanostructures are appropriate riboflavin vehicles until their degradation in the intestine (Madalena et al., 2016). Similar results were obtained by other authors, when encapsulating EGCG in heat-denatured $\beta$-Lg nanohydrogels. They observed that EGCG was just partially released during gastric digestion of nanohydrogels, suggesting that they could be used as EGCG protection vehicles' in the stomach, releasing it in a sustained way in the intestine (Shpigelman et al., 2012).

Another strategy used to overcome protein-based structures instability under GIT conditions is to prevent protein hydrolysis by proteolytic enzymes and gastric acidity through a coating application. In a recent work, a chitosan (Cs) coating has been applied in LF-GMP nanohydrogels by LbL deposition technique (Bourbon et al., 2016b). It was observed that Cs improved GMP and LF stability to gastric digestion, once these proteins were hydrolyzed at a slower rate. Also, nanohydrogels coated with Cs remained intact in solution for a period four times longer than uncoated nanohydrogels, during gastric digestion.

Also, some strategies have been developed to increase the bioaccessibility of bioactive compounds incorporated in protein-based structures. In a recent study, curcumin has been encapsulated in zein nanoparticles (produced by antisolvent precipitation) followed by mixing with lipid nanoparticles (produced by microfluidization) - formation of mixed colloidal 
TABLE 3 | Selected examples of protein-based structures under GIT conditions.

\begin{tabular}{|c|c|c|c|c|}
\hline Scale & Structure & Bioactive compound encapsulated & Behavior under GIT conditions & References \\
\hline \multirow[t]{2}{*}{ Macro } & $\beta$-Lg hydrogels & Iron & $\begin{array}{l}\text { Different iron release profiles depending on } \\
\text { hydrogel microstructure (filamentous or } \\
\text { particulate gels) }\end{array}$ & Remondetto et al., 2004 \\
\hline & PPI-alginate hydrogel matrix & Lactobacillus casei ATCC 393 & $\begin{array}{l}\text { Encapsulation protected the probiotic } \\
\text { against simulated gastric fluid }\end{array}$ & Xu et al., 2016 \\
\hline \multirow{2}{*}{ Micro } & WPC and SC microparticles & Trans-resveratrol & $\begin{array}{l}\text { Encapsulated resveratrol present higher } \\
\text { digestive stability and bioaccessibility in } \\
\text { comparison to free resveratrol. Higher } \\
\text { digestive stability and bioaccessibility } \\
\text { obtained with SC-based microcapsules }\end{array}$ & Koga et al., 2016 \\
\hline & SPI-based microparticles & $\begin{array}{l}\text { Lactobacillus plantarum CECT } 220 \text { and } \\
\text { Lactobacillus casei CECT } 475\end{array}$ & $\begin{array}{l}\text { Probiotic-loaded microparticles enhanced } \\
\text { probiotic viability and tolerance against } \\
\text { simulated GIT fluids }\end{array}$ & $\begin{array}{l}\text { González-Ferrero et al., } \\
2018\end{array}$ \\
\hline \multirow{2}{*}{ Nano } & SC, WPI, and SPI nanocomplexes & CoQ10 & $\begin{array}{l}\text { Complexation improved the stability to } \\
\text { in vitro digestion and CoQ10 } \\
\text { bioaccessibility. Higher CoQ10 } \\
\text { bioaccessibility obtained with milk proteins } \\
\text { compared to SPI }\end{array}$ & Chen et al., 2006 \\
\hline & SC, WPI, and SPI nanoparticles & $\beta$-carotene & $\begin{array}{l}\text { Most advantageous release properties } \\
\text { obtained for WPI nanoparticles: low } \\
\text { release under gastric conditions but high } \\
\text { release under intestinal conditions }\end{array}$ & Yi et al., 2015 \\
\hline
\end{tabular}

PPI, pea protein isolate; $\beta$-Lg, $\beta$-lactoglobulin; WPC, whey protein concentrate; SC, sodium caseinate; WPI, whey protein isolate; SPI, soybean protein isolate; CoQ10, Coenzyme Q10; GIT, gastrointestinal tract.

particles. When lipid nanoparticle concentration increased in the colloidal dispersion, curcumin bioaccessibility increased, which could be explained by the improved mixed micelle phase solubilization capacity (Zou et al., 2016). Similarly, other authors, encapsulated curcumin and resveratrol in core-shell zeinEGCG conjugate nanoparticles. The authors observed that the bioaccessibility of both bioactive compounds was significantly enhanced after lipid droplets (i.e., excipient nanoemulsions) were mixed with the nanoparticles. These results showed that lipophilic bioactive compounds' bioaccessibility and stability can be improve by mixed colloidal delivery systems design (Liu et al., 2018).

\section{Uptake/Absorption}

As previously mentioned, proteins-based structures face various challenges during digestion process including proteolytic enzymes and low $\mathrm{pH}$. In addition, the intestinal barrier is a potential absorption/uptake hurdle to these structures due to different aspects like p-glycoprotein efflux, specific absorption sites, retention/transit time, and mucus layer (Pawar et al., 2014). The small intestine can just carry amino acids or peptides. Usually, they are carried by active transport over the enterocytes membrane using a variety of symporters (e.g., intestinal $\mathrm{H}^{+}$/peptide symport). Then, amino acids are formed due to cytosolic peptidases activity inside the cells and, finally, they are passively transported through the basolateral membrane into the bloodstream (Rubio-Aliaga and Daniel, 2002). Thus, proteins-based structures probably are digested by a range of enzymes (e.g., trypsin and chymotrypsin) preceding absorption. However, it is possible to find some research works where nanoscale protein-based structures were capable to cross the intestinal membrane for example, folic acid-conjugated SPI nanoparticles as a delivery system for curcumin (Teng et al., 2013) and gambogic acid-LF nanoparticles (Zhang et al., 2013).

Different human epithelial cell models are being used to mimic the small intestine conditions. These models allow the study of numerous situations, like absorption, adhesion, bioaccumulation, and potential toxicity of protein-based nanostructures (Gamboa and Leong, 2013; Lefebvre et al., 2014; Cubells-Baeza et al., 2015). Generally, Caco-2 cells (colon carcinoma-derived cells) monocultures are the most used human epithelial cell model, because these cells have the capacity to differentiate into enterocytes-like cells (Lefebvre et al., 2014). However, more complex cellular models can be used, such as Caco-2/HT-29 MTX co-cultures. In this case, HT-29 MTX cells, derived from human colon cells, have the capacity to produce mucin and consequently, a mucous layer (Gamboa and Leong, 2013). Cells can be cultivated on permeable filters under static conditions or afterwards, filters can be used in dynamic diffusion systems, such as the Ussing chamber or a multicompartment 
model (membrane bioreactor) to simulate flow-mediated transport through the intestinal membrane (Antunes et al., 2013; Cubells-Baeza et al., 2015).

Therefore, several absorption/uptake studies have been conducted with nanoscale protein-based structures under simulated small intestine conditions. An example of uptake enhancement is given in the work of Suktham et al. (2018), who created resveratrol-loaded sericin nanoparticles, being sericin obtain from silk. These authors reported that cellular internalization on Caco-2 cells of sericin nanoparticles proved easy and dependent on incubation time. Also, in vitro results indicated sustained release of resveratrol (over $72 \mathrm{~h}$ ) (Suktham et al., 2018).

Another interesting uptake work example has been described by Arranz et al. (2017), where digested rosemary supercritical extract (RSE) was incorporated in oil-in-water emulsions stabilized with various milk proteins (Arranz et al., 2017). The influence of the emulsion on RSE main constituents (carnosol and carnosic acid) bioaccessibility was assessed. Canola oilin-water emulsions were stabilized with LF or WPI. Briefly, RSE encapsulation in emulsion droplets improved carnosic acid delivery. Moreover, there were no differences with protein type, when carnosic acid and carnosol absorption was studied on Caco-2 cells. However, when Caco-2/HT-29 MTX co-cultures were used, a higher carnosic acid retention was observed for LF emulsions due to the presence of mucus layer.

In another study, Akbari et al. (2017) investigated the mucuspenetrating and mucoadhesive properties of two protein-based nanoparticles with coumarin encapsulated based on cruciferin (Cru) (a protein extracted from Canola seeds), Cru/calcium (Cru/Ca), and Cru/chitosan (Cru/Cs) (Akbari et al., 2017). The results showed that $\mathrm{Cru} / \mathrm{Ca}$ nanoparticles were dissociated in the simulated GIT conditions, in contrast to Cru/Cs particles which were not digested. Furthermore, $\mathrm{Cru} / \mathrm{Ca}$ nanoparticles produced a 2- and 6-fold increase in coumarin transport and uptake, respectively. The authors stated that $\mathrm{Cru} / \mathrm{Ca}$ nanoparticles can shield susceptible compounds in the stomach and liberate them in the intestine. Also, Cru/Cs particles can protect encapsulated compounds from gastric and intestine harsh conditions, and the remaining Cs portion can increase the compound uptake because Cs presents mucoadhesive properties.

As previously stated, the change of protein-based structures scale' could lead to novel properties and functionalities, which may improve or reduce absorption of bioactive compounds within structures. Also, the protein-based structure at the nanoscale can more easily pass cellular barrier due to a larger surface area to volume ratio (Zhang et al., 2014). Teo et al. (2017) assessed the uptake and cytotoxicity of lutein in WPI-stabilized nanoemulsions $(68.8 \pm 0.3 \mathrm{~nm})$ on Caco- 2 cells compared to conventional emulsions $(147.3 \pm 0.6 \mathrm{~nm})$. The WPI-stabilized nanoemulsions did not demonstrate cytotoxicity on Caco-2 cells. Also, they concluded that WPI-stabilized nanoemulsions presented a higher lutein cellular uptake $(872.9 \pm 88.3 \mathrm{pmol} / \mathrm{mg}$ protein) when compared to conventional nanoemulsions (329.5 $\pm 214.6 \mathrm{pmol} / \mathrm{mg}$ protein) (Teo et al., 2017).

Furthermore, in some cases, the combination of more than one protein could stabilize carrier-based structures as well as provide them with enhanced absorption capacity. For example, caseinate-coated zein nanoparticles showed good mucoadhesive property, better uptake and permeation across Caco- 2 cells. This process could be enhanced by incubation time extension and higher sodium caseinate concentrations (Luo et al., 2013).

Even though, in vitro cell models used to study absorption/uptake could be a good alternative to in vivo models due to ethical issues and low cost, studies should be also conducted in more complex in vivo systems. For instance, alginate was combined with whey protein to form cold set microparticles as carriers for insulin and in vitro and in vivo insulin absorption studies were conducted (DéatLainé et al., 2012, 2013). In vitro tests were performed in Caco-2 cells and results showed that insulin absorption was enhanced due to whey-alginate microparticles because the two biopolymers opened tight junctions helping insulin passage. In vivo analysis was performed on rats and their plasma glucose levels were examined after duodenal administration of protein-based microparticles loaded with insulin. The authors demonstrated that plasma glucose levels decreased which confirmed that bioactive insulin was transported across the duodenal membrane. Thus, the authors concluded that those structures can be potential insulin delivery systems.

\section{CONCLUDING REMARKS}

In this review, we have documented recent advances in terms of development and characterization of protein-based structures at various scales, to allow their customization as delivery systems for food applications.

Proteins can be provided from low-cost and naturally occurring food components, thus being candidates to be used as green formulation ingredients in the food industry. On the other hand, a disadvantage associated with proteins is their chemical heterogeneity, which leads to variability in their structure and performance properties.

Despite the improvements of protein-based structures' physicochemical properties (e.g., mechanical properties) and functionality, further studies are needed to overcome many remaining limitations in protein-based macro-, micro-, and nanostructures development (e.g., low stability under GIT conditions). Also, future work is needed to better comprehend the link between protein-based structure properties and their functional performance.

Moreover, the particle size will have a direct impact on the food product properties (e.g., appearance, texture, and taste) and on the release behavior of the carried compound and consequently, on its absorption. For example, nanoparticles carrying a bioactive compound can be directly up-taken by the intestinal epithelium, while for hydrogels or microparticles, the bioactive compounds must first be released from the structure.

It is also worth to mention that independently from the scale (i.e., macro, micro-, or nanoscale) there are different approaches to produce protein-based structures (i.e., using one or a sequence of methods), which influence protein 
aggregation and consequently, their physicochemical and functional properties. A deep knowledge of proteins properties' allows their manipulation and takes advantage of them for novel food applications. Hence, the protein choice should be made considering the ingredients used and the final application of the structure.

Furthermore, protein-based structures stability should be tested because these structures may undergo processing conditions (e.g., sterilization) that could change their efficiency as bioactive compounds vehicle'. Also, it will be important to ensure that protein-based structures maintain their functionality within food products and human GIT.

Finally, novel protein-based nanostructures must be studied in detail to guarantee that the dimension reduction is not toxic and is safe for human consumption.

We believe that protein-based structures display such diverse and rich characteristics, which definitely constitutes a prolific ground for innovation in the field of sustainable functional structures for the food industry.

\section{REFERENCES}

Abbasi, A., Emam-Djomeh, Z., Mousavi, M. A. E., and Davoodi, D. (2014). Stability of vitamin D3 encapsulated in nanoparticles of whey protein isolate. Food Chem. 143, 379-383. doi: 10.1016/j.foodchem.2013.08.018

Abeyrathne, E. D., Lee, H. Y., and Ahn, D. U. (2013). Egg white proteins and their potential use in food processing or as nutraceutical and pharmaceutical agents-a review. Poult. Sci. 92, 3292-3299. doi: 10.3382/ps.2013-03391

Adamczak, M. I., Hagesaether, E., Smistad, G., and Hiorth, M. (2016). An in vitro study of mucoadhesion and biocompatibility of polymer coated liposomes on HT29-MTX mucus-producing cells. Int. J. Pharm. 498, 225-233. doi: 10.1016/j.ijpharm.2015.12.030

Adams, S., Frith, W. J., and Stokes, J. R. (2004). Influence of particle modulus on the rheological properties of agar microgel suspensions. J. Rheol. 48, 1195-1195. doi: $10.1122 / 1.1795193$

Aditya, N. P., Espinosa, Y. G., and Norton, I. T. (2017). Encapsulation systems for the delivery of hydrophilic nutraceuticals: food application. Biotechnol. Adv. 35, 450-457. doi: 10.1016/j.biotechadv.2017.03.012

Aguilera, J. M., and Rademacher, B. (2004). "Protein gels," in Proteins in Food Processing, ed R. Y. Yada (Cambridge: Woodhead Publishing Limited), $468-482$.

Akbari, A., Lavasanifar, A., and Wu, J. (2017). Interaction of cruciferin-based nanoparticles with Caco-2 cells and Caco-2/HT29-MTX co-cultures. Acta Biomater. 64, 249-258. doi: 10.1016/j.actbio.2017.10.017

Akkermans, C., Van der Goot, A. J., Venema, P., Gruppen, H., Vereijken, J. M., Van der Linden, E., et al. (2007). Micrometer-sized fibrillar protein aggregates from soy glycinin and soy protein isolate. J. Agric. Food Chem. 55, 9877-9882. doi: 10.1021/jf0718897

Anaya Castro, M. A., Alric, I., Brouillet, F., Peydecastaing, J., Fullana, S. G., and Durrieu, V. (2018). Soy protein microparticles for enhanced oral ibuprofen delivery: preparation, characterization, and in vitro release evaluation. AAPS PharmSciTech. 19, 1124-1132. doi: 10.1208/s12249-017-0928-5

Antunes, F., Andrade, F., Ferreira, D., Nielsen, H. M., and Sarmento, B. (2013). Models to predict intestinal absorption of therapeutic peptides and proteins. Curr. Drug Metab. 14, 4-20. doi: 10.2174/138920013804545160

Arangoa, M. A., Campanero, M. A., Renedo, M. J., Ponchel, G., and Irache, J. M. (2001). Gliadin nanoparticles as carriers for the oral administration of lipophilic drugs. Relationships between bioadhesion and pharmacokinetics. Pharm. Res. 18, 1521-1527. doi: 10.1023/A:1013018111829

Arranz, E., Guri, A., Fornari, T., Mendiola, J. A., Reglero, G., and Corredig, M. (2017). In vitro uptake and immune functionality of digested Rosemary

\section{AUTHOR CONTRIBUTIONS}

$\mathrm{JM}, \mathrm{AB}, \mathrm{AP}$, and LF contributed to conception, design, writing, and revision of the manuscript. AV contributed to revision of the manuscript. All authors read and approved the submitted version.

\section{ACKNOWLEDGMENTS}

$\mathrm{JM}$ and AP acknowledge the Portuguese Foundation for Science and Technology (FCT) for their fellowships (SFRH/BPD/89992/2012 and SFRH/BPD/101181/2014). This work was supported by Portuguese FCT under the scope of the Project PTDC/AGR-TEC/5215/2014, of the strategic funding of UID/BIO/04469 unit and COMPETE 2020 (POCI-01-0145-FEDER-006684), and BioTecNorte operation (NORTE-01-0145-FEDER-000004) funded by the European Regional Development Fund under the scope of Norte2020-Programa Operacional Regional do Norte.

extract delivered through food grade vehicles. Food Res. Int. 97, 71-77. doi: 10.1016/j.foodres.2017.03.033

Babin, H., and Dickinson, E. (2001). Influence of transglutaminase treatment on the thermoreversible gelation of gelatin. Food Hydrocolloids 15, 271-276. doi: 10.1016/S0268-005X(01)00025-X

Baigts Allende, D., and De Jongh, H. H. J. (2015). Calcium binding restores gel formation of succinylated gelatin and reduces brittleness with preservation of the elastically stored energy. J. Agric. Food Chem. 63, 7058-7065. doi: 10.1021/acs.jafc.5b01962

Baranauskiene, R., Venskutonis, P. R., Dewettinck, K., and Verhé, R. (2006). Properties of oregano (Origanum vulgare L.), citronella (Cymbopogon nardus G.) and marjoram (Majorana hortensis L.) flavors encapsulated into milk protein-based matrices. Food Res. Int. 39, 413-425. doi: 10.1016/j.foodres.2005.09.005

Bi, C. H., Li, D., Wang, L. J., and Adhikari, B. (2013). Viscoelastic properties and fractal analysis of acid-induced SPI gels at different ionic strength. Carbohydr. Polym. 92, 98-105. doi: 10.1016/j.carbpol.2012.08.081

Bodini, R. B., Sobral, P. J. A., Favaro-Trindade, C. S., and Carvalho, R. A. (2013). Properties of gelatin-based films with added ethanol-propolis extract. LWT Food Sci. Technol. 51, 104-110. doi: 10.1016/j.lwt.2012.10.013

Bokkhim, H., Bansal, N., GrØndahl, L., and Bhandari, B. (2013). Physico-chemical properties of different forms of bovine lactoferrin. Food Chem. 141, 3007-3013. doi: 10.1016/j.foodchem.2013.05.139

Bourbon, A. I., Cerqueira, M. A., and Vicente, A. A. (2016a). Encapsulation and controlled release of bioactive compounds in lactoferrin-glycomacropeptide nanohydrogels: Curcumin and caffeine as model compounds. J. Food Eng. 180, 110-119. doi: 10.1016/j.jfoodeng.2016.02.016

Bourbon, A. I., Pinheiro, A. C., Cerqueira, M. A., and Vicente, A. A. (2016b). Influence of chitosan coating on protein-based nanohydrogels properties and in vitro gastric digestibility. Food Hydrocolloids 60, 109-118. doi: 10.1016/j.foodhyd.2016.03.002

Boye, J. I., Alli, I., Ismail, A. A., Gibbs, B. F., and Konishi, Y. (1995). Factors affecting molecular characteristics of whey protein gelation. Int. Dairy J. 5, 337-353. doi: 10.1016/0958-6946(94)00012-E

Boye, J. I., Ma, C. Y., Ismail, A., Harwalkar, V. R., and Kalab, M. (1997). Molecular and microstructural studies of thermal denaturation and gelation of $\beta$-lactoglobulins A and B. J. Agric. Food Chem. 45, 1608-1618. doi: 10.1021/jf960622x

Bryant, C. M., and McClements, D. J. (2000). Influence of $\mathrm{NaCl}$ and $\mathrm{CaCl}_{2}$ on cold-set gelation of heat-denatured whey protein. J. Food Sci. 65, 801-804. doi: 10.1111/j.1365-2621.2000.tb13590.x 
Campbell, L., Raikos, V., and Euston, S. R. (2003). Modification of functional properties of egg-white proteins. Nahrung 47, 369-376. doi: 10.1002/food.200390084

Can Karaca, A., Low, N. H., and Nickerson, M. T. (2015). Potential use of plant proteins in the microencapsulation of lipophilic materials in foods. Trends Food Sci. Technol. 42, 5-12. doi: 10.1016/j.tifs.2014.11.002

Chang, C., Li, J., Li, X., Wang, C., Zhou, B., Su, Y., et al. (2017). Effect of protein microparticle and pectin on properties of light mayonnaise. LWT Food Sci. Technol. 82, 8-14. doi: 10.1016/j.lwt.2017.04.013

Chang, C., Niu, F., Gu, L., Li, X., Yang, H., Zhou, B., et al. (2016). Formation of fibrous or granular egg white protein microparticles and properties of the integrated emulsions. Food Hydrocolloids 61, 477-486. doi: 10.1016/j.foodhyd.2016.06.002

Chen, J., Zheng, J., McClements, D. J., and Xiao, H. (2014). Tangeretinloaded protein nanoparticles fabricated from zein/ $\beta$-lactoglobulin: preparation, characterization, and functional performance. Food Chem. 158, 466-472. doi: 10.1016/j.foodchem.2014.03.003

Chen, L., Remondetto, G. E., and Subirade, M. (2006). Food protein-based materials as nutraceutical delivery systems. Trends Food Sci. Technol. 17, 272-283. doi: 10.1016/j.tifs.2005.12.011

Chen, L., and Subirade, M. (2009). Elaboration and characterization of soy/zein protein microspheres for controlled nutraceutical delivery. Biomacromolecules 10, 3327-3334. doi: 10.1021/bm900989y

Chen, N., Zhao, M., Chassenieux, C., and Nicolai, T. (2017a). The effect of adding $\mathrm{NaCl}$ on thermal aggregation and gelation of soy protein isolate. Food Hydrocolloids 70, 88-95. doi: 10.1016/j.foodhyd.2017. 03.024

Chen, N., Zhao, M., Niepceron, F., Nicolai, T., and Chassenieux, C. (2017b). The effect of the $\mathrm{pH}$ on thermal aggregation and gelation of soy proteins. Food Hydrocolloids 66, 27-36. doi: 10.1016/j.foodhyd.2016.12.006

Chung, C., Degner, B., and McClements, D. J. (2014). Development of reducedcalorie foods: microparticulated whey proteins as fat mimetics in semi-solid food emulsions. Food Res. Int. 56, 136-145. doi: 10.1016/j.foodres.2013.11.034

Clark, A. H., Kavanagh, G. M., and Ross-Murphy, S. B. (2001). Globular protein gelation-theory and experiment. Food Hydrocolloids 15, 383-400. doi: 10.1016/S0268-005X(01)00042-X

Cooksey, K., Marsh, K. S., and Doar, L. H. (1999). Predicting permeability \& transmission rate for multilayer materials. Food Technol. 53, 60-63.

Croguennec, T., Nau, F., and Brulé, G. (2002). Influence of $\mathrm{pH}$ and salts on egg white gelation. J. Food Sci. 67, 608-614. doi: 10.1111/j.1365-2621.2002.tb10646.x

Cubells-Baeza, N., Verhoeckx, K. C. M., Larre, C., Denery-Papini, S., GavrovicJankulovic, M., and Diaz Perales, A. (2015). Applicability of epithelial models in protein permeability/transport studies and food allergy. Drug Discov. Today 17-18, 13-21. doi: 10.1016/j.ddmod.2016.08.002

Damodaran, S. (1997). Food Proteins and Their Applications. New York, NY: Marcel Dekker, Inc.

Davidov-Pardo, G., Joye, I. J., and McClements, D. J. (2015). "Food-grade protein-based nanoparticles and microparticles for bioactive delivery: fabrication, characterization, and utilization," in Advances in Protein Chemistry and Structural Biology, ed D. Rossen (Oxford: Academic Press), 293-325.

de Castro, R. J. S., Domingues, M. A. F., Ohara, A., Okuro, P. K., dos Santos, J. G., Brexó, R. P., et al. (2017). Whey protein as a key component in food systems: physicochemical properties, production technologies and applications. Food Struct. 14, 17-29. doi: 10.1016/j.foostr.2017.05.004

de Souza Simões, L., Madalena, D. A., Pinheiro, A. C., Teixeira, J. A., Vicente, A. A., and Ramos, Ó. L. (2017). Micro- and nano bio-based delivery systems for food applications: in vitro behavior. Adv. Colloid Interface Sci. 243, 23-45. doi: 10.1016/j.cis.2017.02.010

Déat-Lainé, E., Hoffart, V., Garrait, G., and Beyssac, E. (2013). Whey protein and alginate hydrogel microparticles for insulin intestinal absorption: evaluation of permeability enhancement properties on Caco-2 cells. Int. J. Pharm. 453, 336-342. doi: 10.1016/j.ijpharm.2013.06.016

Déat-Lainé, E., Hoffart, V., Garrait, G., Jarrige, J.-F., Cardot, J.-M., Subirade, M., et al. (2012). Efficacy of mucoadhesive hydrogel microparticles of whey protein and alginate for oral insulin delivery. Pharm. Res. 30, 721-734. doi: $10.1007 /$ s11095-012-0913-3
Dekkers, B. L., Kolodziejczyk, E., Acquistapace, S., Engmann, J., and Wooster, T. J. (2016). Impact of gastric $\mathrm{pH}$ profiles on the proteolytic digestion of mixed Blg-Xanthan biopolymer gels. Food Funct. 7, 58-68. doi: 10.1039/C5FO01085C

Dickinson, E. (2012). Use of nanoparticles and microparticles in the formation and stabilization of food emulsions. Trends Food Sci. Technol. 24, 4-12. doi: 10.1016/j.tifs.2011.09.006

Dickinson, E. (2015). Microgels - an alternative colloidal ingredient for stabilization of food emulsions. Trends Food Sci. Technol. 43, 178-188. doi: 10.1016/j.tifs.2015.02.006

Doherty, S. B., Gee, V. L., Ross, R. P., Stanton, C., Fitzgerald, G. F., and Brodkorb, A. (2011). Development and characterisation of whey protein micro-beads as potential matrices for probiotic protection. Food Hydrocolloids 25, 1604-1617. doi: 10.1016/j.foodhyd.2010.12.012

Duranti, M. (2006). Grain legume proteins and nutraceutical properties. Fitoterapia 77, 67-82. doi: 10.1016/j.fitote.2005.11.008

Egan, T., O’Riordan, D., O'Sullivan, M., and Jacquier, J. C. (2014). Cold-set whey protein microgels as $\mathrm{pH}$ modulated immobilisation matrices for charged bioactives. Food Chem. 156, 197-203. doi: 10.1016/j.foodchem.2014.01.109

Elzoghby, A. O., Samy, W. M., and Elgindy, N. A. (2012). Protein-based nanocarriers as promising drug and gene delivery systems. J. Controll. Release 161, 38-49. doi: 10.1016/j.jconrel.2012.04.036

Fazani Cavallieri, Â. L., Garcez, M. M., Takeuchi, K. P., and da Cunha, R. L. (2010). Heat-induced gels of soy protein and $\kappa$-carrageenan at different $\mathrm{pH}$ values. Int. J. Food Sci. Technol. 45, 1130-1137. doi: 10.1111/j.1365-2621.2010.02247.x

Feng, J., Wu, S., Wang, H., and Liu, S. (2016). Improved bioavailability of curcumin in ovalbumin-dextran nanogels prepared by Maillard reaction. J. Funct. Foods 27, 55-68. doi: 10.1016/j.jff.2016.09.002

Gamboa, J. M., and Leong, K. W. (2013). In vitro and in vivo models for the study of oral delivery of nanoparticles. Adv. Drug Deliv. Rev. 65, 800-810. doi: 10.1016/j.addr.2013.01.003

Giroux, H. J., and Britten, M. (2011). Encapsulation of hydrophobic aroma in whey protein nanoparticles. J. Microencapsul. 28, 337-343. doi: 10.3109/02652048.2011.569761

Gómez-Mascaraque, L. G., Soler, C., and Lopez-Rubio, A. (2016). Stability and bioaccessibility of EGCG within edible micro-hydrogels. Chitosan vs. gelatin, a comparative study. Food Hydrocolloids 61, 128-138. doi: 10.1016/j.foodhyd.2016.05.009

Gonçalves, R. F. S., Martins, J. T., Duarte, C. M. M., Vicente, A. A., and Pinheiro, A. C. (2018). Advances in nutraceutical delivery systems: from formulation design for bioavailability enhancement to efficacy and safety evaluation. Trends Food Sci. Technol. 78, 270-291. doi: 10.1016/j.tifs.2018.06.011

González-Ferrero, C., Irache, J. M., and González-Navarro, C. J. (2018). Soybean protein-based microparticles for oral delivery of probiotics with improved stability during storage and gut resistance. Food Chem. 239, 879-888. doi: 10.1016/j.foodchem.2017.07.022

Gouin, S. (2004). Microencapsulation: industrial appraisal of existing technologies and trends. Trends Food Sci. Technol. 15, 330-347. doi: $10.1016 /$ j.tifs.2003.10.005

Graveland-Bikker, J. F., and de Kruif, C. G. (2006). Unique milk protein based nanotubes: food and nanotechnology meet. Trends Food Sci. Technol. 17, 196-203. doi: 10.1016/j.tifs.2005.12.009

Gulrez, S. K. H., Al-Assaf, S., and Phillips, G. O. (2011). "Hydrogels: methods of preparation, characterisation and applications," in Progress in Molecular and Environmental Bioengineering - From Analysis and Modeling to Technology Applications, ed A. Carpi (Rijeka: InTech), 117-150.

Gunasekaran, S., Xiao, L., and Ould Eleya, M. M. (2006). Whey protein concentrate hydrogels as bioactive carriers. J. Appl. Polym. Sci. 99, 2470-2476. doi: 10.1002/app.22838

Guo, J., Zhou, Q., Liu, Y. C., Yang, X. Q., Wang, J. M., Yin, S. W., et al. (2016). Preparation of soy protein-based microgel particles using a hydrogel homogenizing strategy and their interfacial properties. Food Hydrocolloids 58, 324-334. doi: 10.1016/j.foodhyd.2016.03.008

Guo, Y., Harris, P., Kaur, A., Pastrana, L., and Jauregi, P. (2017). Characterisation of $\beta$-lactoglobulin nanoparticles and their binding to caffeine. Food Hydrocolloids 71, 85-93. doi: 10.1016/j.foodhyd.2017.04.027

Gupta, P., and Nayak, K. K. (2015). Characteristics of protein-based biopolymer and its application. Polym. Eng. Sci. 55, 485-498. doi: 10.1002/pen. 23928 
He, X., and Hwang, H.-M. (2016). Nanotechnology in food science: functionality, applicability, and safety assessment. J. Food Drug Anal. 24, 671-681. doi: 10.1016/j.jfda.2016.06.001

Hellio, D., and Djabourov, M. (2006). Physically and chemically crosslinked gelatin gels. Macromol. Symp. 241, 23-27. doi: 10.1002/masy.200650904

Huntington, J. A., and Stein, P. E. (2001). Structure and properties of ovalbumin. J. Chromatogr. B 756, 189-198. doi: 10.1016/S0378-4347(01)00108-6

Iwashita, K., Inoue, N., Handa, A., and Shiraki, K. (2015). Thermal aggregation of hen egg white proteins in the presence of salts. Protein J. 34, 212-219. doi: $10.1007 / \mathrm{s} 10930-015-9612-3$

Jiang, Y., Chen, J., Deng, C., Suuronen, E. J., and Zhong, Z. (2014). Click hydrogels, microgels and nanogels: emerging platforms for drug delivery and tissue engineering. Biomaterials 35, 4969-4985. doi: 10.1016/j.biomaterials.2014.03.001

Jones, O. G., and McClements, D. J. (2010). Functional biopolymer particles: design, fabrication, and applications. Compr. Rev. Food Sci. Food Saf. 9, 374-397. doi: 10.1111/j.1541-4337.2010.00118.x

Jones, O. G., and McClements, D. J. (2011). Recent progress in biopolymer nanoparticle and microparticle formation by heat-treating electrostatic protein-polysaccharide complexes. Adv. Colloid Interface Sci. 167, 49-62. doi: 10.1016/j.cis.2010.10.006

Jouenne, E., and Crouzet, J. (2000). Effect of $\mathrm{pH}$ on retention of aroma compounds by $\beta$-lactoglobulin. J. Agric. Food Chem. 48, 1273-1277. doi: 10.1021/jf990215w

Joye, I. J., and McClements, D. J. (2014). Biopolymer-based nanoparticles and microparticles: fabrication, characterization, and application. Curr. Opin. Colloid Interface Sci. 19, 417-427. doi: 10.1016/j.cocis.2014.07.002

Kayitmazer, A. B., Seeman, D., Minsky, B. B., Dubin, P. L., and Xu, Y. (2013). Protein-polyelectrolyte interactions. Soft Matter. 9, 2553-2583. doi: $10.1039 / \mathrm{c} 2 \mathrm{sm} 27002 \mathrm{a}$

Khare, A. R., and Vasisht, N. (2014). "Nanoencapsulation in the food industry: technology of the future," in Microencapsulation in the Food Industry, eds A. G. Gaonkar, N. Vasisht, A. R. Khare, and R. Sobel (San Diego, CA: Academic Press), 151-155.

Kinsella, J. (1979). Functional properties of soy proteins. J. Am. Oil Chem. Soc. 56, 242-258. doi: 10.1007/BF02671468

Kinsella, J. E., and Melachouris, N. (1976). Functional properties of proteins in foods: a survey. CRC Critic. Rev. Food Sci. Nutr. 7, 219-280. doi: $10.1080 / 10408397609527208$

Koga, C. C., Andrade, J. E., Ferruzzi, M. G., and Lee, Y. (2016). Stability of trans-resveratrol encapsulated in a protein matrix produced using spray drying to UV light stress and simulated gastro-intestinal digestion. J. Food Sci. 81, C292-C300. doi: 10.1111/1750-3841.13176

Kuhn, K. R., Cavallieri, Â. L. F., and da Cunha, R. L. (2010). Cold-set whey protein gels induced by calcium or sodium salt addition. Int. J. Food Sci. Technol. 45, 348-357. doi: 10.1111/j.1365-2621.2009.02145.x

Kuhn, K. R., Picone, C. S. F., and Cunha, R. L. (2012). "Food gels," in Biopolymer Engineering in Food Processing, ed V. R. N. Telis (Boca Raton, FL: CRC Press), 111-144.

Lam, R. S. H., and Nickerson, M. T. (2013). Food proteins: a review on their emulsifying properties using a structure-function approach. Food Chem. 141, 975-984. doi: 10.1016/j.foodchem.2013.04.038

Lefebvre, D. E., Venema, K., Gombau, L., Valerio, L. G., Raju, J., Bondy, G. S., et al. (2014). Utility of models of the gastrointestinal tract for assessment of the digestion and absorption of engineered nanomaterials released from food matrices. Nanotoxicology 9, 523-542. doi: 10.3109/17435390.2014.948091

Lefèvre, T., Byette, F., Marcotte, I., and Auger, M. (2014). "Protein- and peptidebased materials: a source of inspiration for innovation," in Functional Materials - For Energy, Sustainable Development and Biomedical Sciences, eds M. Leclerc and R. Gauvin (Berlin: De Gruyter), 415-442.

Leon, A. M., Medina, W. T., Park, D. J., and Aguilera, J. M. (2016). Mechanical properties of whey protein/Na alginate gel microparticles. J. Food Eng. 188, 1-7. doi: 10.1016/j.jfoodeng.2016.05.005

Li, J., Zhang, Y., Fan, Q., Teng, C., Xie, W., Shi, Y., et al. (2018). Combination effects of $\mathrm{NaOH}$ and $\mathrm{NaCl}$ on the rheology and gel characteristics of hen egg white proteins. Food Chem. 250, 1-6. doi: 10.1016/j.foodchem.2018.01.031

Li, M., Ma, Y., and Ngadi, M. O. (2013). Binding of curcumin to $\beta$-lactoglobulin and its effect on antioxidant characteristics of curcumin. Food Chem. 141, 1504-1511. doi: 10.1016/j.foodchem.2013.02.099
Lin, D., Lu, W., Kelly, A. L., Zhang, L., Zheng, B., and Miao, S. (2017). Interactions of vegetable proteins with other polymers: structure-function relationships and applications in the food industry. Trends Food Sci. Technol. 68, 130-144. doi: 10.1016/j.tifs.2017.08.006

Liu, F., Ma, D., Luo, X., Zhang, Z., He, L., Gao, Y., et al. (2018). Fabrication and characterization of protein-phenolic conjugate nanoparticles for codelivery of curcumin and resveratrol. Food Hydrocolloids 79, 450-461. doi: 10.1016/j.foodhyd.2018.01.017

Liu, F., Ou, S. Y., and Tang, C. H. (2017). $\mathrm{Ca}^{2+}$-induced soy protein nanoparticles as pickering stabilizers: fabrication and characterization. Food Hydrocolloids 65, 175-186. doi: 10.1016/j.foodhyd.2016.11.011

Liu, F., and Tang, C. H. (2013). Soy protein nanoparticle aggregates as pickering stabilizers for oil-in-water emulsions. J. Agric. Food Chem. 61, 8888-8898. doi: $10.1021 /$ jf401859y

Liu, Y., Huang, Q., Wang, J., Fu, F., Ren, J., and Zhao, Y. (2017). Microfluidic generation of egg-derived protein microcarriers for 3D cell culture and drug delivery. Sci. Bull. 62, 1283-1290. doi: 10.1016/j.scib.2017.09.006

Livney, Y. D. (2010). Milk proteins as vehicles for bioactives. Curr. Opin. Colloid Interface Sci. 15, 73-83. doi: 10.1016/j.cocis.2009.11.002

Livney, Y. D. (2015). Nanostructured delivery systems in food: latest developments and potential future directions. Curr. Opin. Food Sci. 3, 125-135. doi: 10.1016/j.cofs.2015.06.010

Lohcharoenkal, W., Wang, L., Chen, Y. C., and Rojanasakul, Y. (2014). Protein nanoparticles as drug delivery carriers for cancer therapy. Biomed. Res. Int. 2014, 1-12. doi: 10.1155/2014/180549

Lucca, P. A., and Tepper, B. J. (1994). Fat replacers and the functionality of fat in foods. Trends Food Sci. Technol. 5, 12-19. doi: 10.1016/0924-2244(94)90043-4

Luo, Y., Teng, Z., Wang, T. T. Y., and Wang, Q. (2013). Cellular uptake and transport of zein nanoparticles: effects of sodium caseinate. J. Agric. Food Chem. 61, 7621-7629. doi: 10.1021/jf402198r

Ma, S., Shi, C., Wang, C., and Guo, M. (2017). Effects of ultrasound treatment on physiochemical properties and antimicrobial activities of whey protein-totarol nanoparticles. J. Food Protect. 80:1657-1665. doi: 10.4315/0362-028X.JFP-17-078

Madalena, D. A., Ramos, Ó. L., Pereira, R. N., Bourbon, A. I., Pinheiro, A. C., Malcata, F. X., et al. (2016). In vitro digestion and stability assessment of $\beta$-lactoglobulin/riboflavin nanostructures. Food Hydrocolloids 58, 89-97. doi: 10.1016/j.foodhyd.2016.02.015

Maki, Y., Watabe, S., Dobashi, T., and Matsuo, K. (2014). Effect of sugars on aging of gelatin gels by vacuum-ultraviolet circular dichroism and rheological measurements. J. Biorheol. 28, 38-44. doi: 10.17106/jbr.28.38

Malik, V. S., Li, Y., Tobias, D. K., Pan, A., and Hu, F. B. (2016). Dietary protein intake and risk of type 2 diabetes in US men and women. Am. J. Epidemiol. 183, 715-728. doi: 10.1093/aje/kwv268

Maltais, A., Remondetto, G. E., Gonzalez, R., and Subirade, M. (2005). Formation of soy protein isolate cold-set gels: protein and salt effects. J. Food Sci. 70, C67-C73. doi: 10.1111/j.1365-2621.2005.tb09023.x

Maltais, A., Remondetto, G. E., and Subirade, M. (2008). Mechanisms involved in the formation and structure of soya protein cold-set gels: a molecular and supramolecular investigation. Food Hydrocolloids 22, 550-559. doi: 10.1016/j.foodhyd.2007.01.026

Martins, J. T., Ramos, Ó. L., Pinheiro, A. C., Bourbon, A. I., Silva, H. D., Rivera, M. C., et al. (2015). Edible bio-based nanostructures: delivery, absorption and potential toxicity. Food Eng. Rev. 7, 491-513. doi: 10.1007/s12393-015-9116-0

Martins, J. T., Santos, S. F., Bourbon, A. I., Pinheiro, A. C., González-Fernández, Á., Pastrana, L. M., et al. (2016). Lactoferrin-based nanoparticles as a vehicle for iron in food applications - development and release profile. Food Res. Int. 90 (Suppl. C), 16-24. doi: 10.1016/j.foodres.2016.10.027

Matalanis, A., Jones, O. G., and McClements, D. J. (2011). Structured biopolymer-based delivery systems for encapsulation, protection, and release of lipophilic compounds. Food Hydrocolloids 25, 1865-1880. doi: 10.1016/j.foodhyd.2011.04.014

Matsumiya, K., and Murray, B. S. (2016). Soybean protein isolate gel particles as foaming and emulsifying agents. Food Hydrocolloids 60, 206-215. doi: $10.1016 /$ j.foodhyd.2016.03.028

McClements, D. J. (2017). The future of food colloids: next-generation nanoparticle delivery systems. Curr. Opin. Colloid Interface Sci. 28, 7-14. doi: $10.1016 /$ j.cocis.2016.12.002 
McClements, D. J. (eds.). (2014). "Key physicochemical concepts," in Nanoparticleand Microparticle-Based Delivery Systems: Encapsulation, Protection and Release of Active Compounds (Boca Raton, FL: CRC Press), 453-514.

McClements, D. J., Decker, E. A., Park, Y., and Weiss, J. (2009). Structural design principles for delivery of bioactive components in nutraceuticals and functional foods. Crit. Rev. Food Sci. Nutr. 49, 577-606. doi: 10.1080/10408390902841529

McClements, D. J., and Rao, J. (2011). Food-grade nanoemulsions: formulation, fabrication, properties, performance, biological fate, and potential toxicity. Crit. Rev. Food Sci. Nutr. 51, 285-330. doi: 10.1080/10408398.2011.559558

McKee, T., and McKee, J. R. (2015). "Amino acids, peptides, and proteins," in Biochemistry: The Molecular Basis of Life, 5th Edn., eds T. McKee and J. R. McKee (New York, NY: Oxford University Press), 123-181.

Medina-Torres, L., Calderas, F., Gallegos-Infante, A. A., Gonzalez-Laredo, R. F., Rocha-Guzman, N. E., and Harte, F. (2010). Mechanical properties of ovalbumin gels formed at different conditions of Concentration, ionic strength, $\mathrm{pH}$, and aging time. Food Bioprocess Technol. 3, 150-154. doi: 10.1007/s11947-009-0257-0

Mirafzali, Z., Thompson, C. S., and Tallua, K. (2014). "Application of liposomes in the food industry," in Microencapsulation in the Food Industry, eds A. G. Gaonkar, N. Vasisht, A. R. Khare, and R. Sobel (San Diego, CA: Academic Press), 139-150.

Moschakis, T. (2013). Microrheology and particle tracking in food gels and emulsions. Curr. Opin. Colloid Interface Sci. 18, 311-323. doi: 10.1016/j.cocis.2013.04.011

Muschiolik, G., and Dickinson, E. (2017). Double emulsions relevant to food systems: preparation, stability, and applications. Compr. Rev. Food Sci. Food Saf. 16, 532-555. doi: 10.1111/1541-4337.12261

Nazir, A., Asghar, A., and Aslam Maan, A. (2016). Food gels: gelling process and new applications. Adv. Food Rheol. Appl. 52, 335-353. doi: 10.1016/b978-0-08-100431-9.00013-9

Neethirajan, S., and Jayas, D. S. (2011). Nanotechnology for the food and bioprocessing industries. Food Bioprocess Technol. 4, 39-47. doi: 10.1007/s11947-010-0328-2

Neo, Y. P., Ray, S., Jin, J., Gizdavic-Nikolaidis, M., Nieuwoudt, M. K., Liu, D., et al. (2013). Encapsulation of food grade antioxidant in natural biopolymer by electrospinning technique: a physicochemical study based on zein-gallic acid system. Food Chem. 136, 1013-1021. doi: 10.1016/j.foodchem.2012. 09.010

Ngan, C. L., Basri, M., Lye, F. F., Fard Masoumi, H. R., Tripathy, M., Karjiban, R. A., et al. (2014). Comparison of process parameter optimization using different designs in nanoemulsion-based formulation for transdermal delivery of fullerene. Int. J. Nanomed. 9, 4375-4386. doi: 10.2147/IJN. S65689

Nicolai, T., and Durand, D. (2013). Controlled food protein aggregation for new functionality. Curr. Opin. Colloid Interface Sci. 18, 249-256. doi: 10.1016/j.cocis.2013.03.001

Nishinari, K., Fang, Y., Guo, S., and Phillips, G. O. (2014). Soy proteins: a review on composition, aggregation and emulsification. Food Hydrocolloids 39, 301-318. doi: 10.1016/j.foodhyd.2014.01.013

Nojima, T., and Iyoda, T. (2018). Egg white-based strong hydrogel via ordered protein condensation. NPG Asia Mater. 10:e460. doi: 10.1038/am.20 17.219

Okuro, P. K., Furtado, G. F., Sato, A. C. K., and Cunha, R. L. (2015). Structures design for protection and vehiculation of bioactives. Curr. Opin. Food Sci. 5, 67-75. doi: 10.1016/j.cofs.2015.09.003

O’Neill, G. J., Jacquier, J. C., Mukhopadhya, A., Egan, T., O'Sullivan, M., Sweeney, T., et al. (2015). In vitro and in vivo evaluation of whey protein hydrogels for oral delivery of riboflavin. J. Funct. Foods 19, 512-521. doi: $10.1016 /$ j.jff.2015.09.043

Ozel, B., Cikrikci, S., Aydin, O., and Oztop, M. H. (2017). Polysaccharide blended whey protein isolate-(WPI) hydrogels: a physicochemical and controlled release study. Food Hydrocolloids 71, 35-46. doi: 10.1016/j.foodhyd.2017.04.031

Pan, K., Zhong, Q., and Baek, S. J. (2013). Enhanced dispersibility and bioactivity of curcumin by encapsulation in casein nanocapsules. J. Agric. Food Chem. 61, 6036-6043. doi: 10.1021/jf400752a

Patel, A. R., Bouwens, E. C. M., and Velikov, K. P. (2010). Sodium caseinate stabilized zein colloidal particles. J. Agric. Food Chem. 58, 12497-12503. doi: $10.1021 /$ jf $102959 b$
Patel, A. R., and Velikov, K. P. (2014). Zein as a source of functional colloidal nano- and microstructures. Curr. Opin. Colloid Interface Sci. 19, 450-458. doi: 10.1016/j.cocis.2014.08.001

Pawar, V. K., Meher, J. G., Singh, Y., Chaurasia, M., Surendar Reddy, B., and Chourasia, M. K. (2014). Targeting of gastrointestinal tract for amended delivery of protein/peptide therapeutics: strategies and industrial perspectives. J. Controll. Release 196, 168-183. doi: 10.1016/j.jconrel.2014.09.031

Peng, D., Jin, W., Tang, C., Lu, Y., Wang, W., Li, J., et al. (2018). Foaming and surface properties of gliadin nanoparticles: influence of $\mathrm{pH}$ and heating temperature. Food Hydrocolloids 77, 107-116. doi: 10.1016/j.foodhyd.2017.09.026

Pepe, A., Podesva, P., and Simone, G. (2017). Tunable uptake/release mechanism of protein microgel particles in biomimicking environment. Sci. Rep. 7:6014. doi: 10.1038/s41598-017-06512-5

Perrechil, F. A., Sato, A. C. K., and Cunha, R. L. (2011). к-Carrageenansodium caseinate microgel production by atomization: critical analysis of the experimental procedure. J. Food Eng. 104, 123-133. doi: 10.1016/j.jfoodeng.2010.12.004

Peters, J. P. C. M., Luyten, H., Alting, A. C., Boom, R. M., and Van der Goot, A. J. (2015). Effect of crosslink density on the water-binding capacity of whey protein microparticles. Food Hydrocolloids 44, 277-284. doi: 10.1016/j.foodhyd.2014.09.030

Peters, J. P. C. M., Vergeldt, F. J., Van As, H., Luyten, H., Boom, R. M., and van der Goot, A. J. (2017). Unravelling of the water-binding capacity of cold-gelated whey protein microparticles. Food Hydrocolloids 63, 533-544. doi: 10.1016/j.foodhyd.2016.09.038

Picone, C. S. F., Takeuchi, K. P., and Cunha, R. L. (2011). Heat-induced whey protein gels: effects of $\mathrm{pH}$ and the addition of sodium caseinate. Food Biophys. 6, 77-83. doi: 10.1007/s11483-010-9177-9

Picot, A., and Lacroix, C. (2004). Encapsulation of bifidobacteria in whey proteinbased microcapsules and survival in simulated gastrointestinal conditions and in yoghurt. Int. Dairy J. 14, 505-515. doi: 10.1016/j.idairyj.2003.10.008

Pujara, N., Jambhrunkar, S., Wong, K. Y., McGuckin, M., and Popat, A. (2017). Enhanced colloidal stability, solubility and rapid dissolution of resveratrol by nanocomplexation with soy protein isolate. J. Colloid Interface Sci. 488, 303-308. doi: 10.1016/j.jcis.2016.11.015

Qiu, C., Zhao, M., Decker, E. A., and McClements, D. J. (2015). Influence of protein type on oxidation and digestibility of fish oil-in-water emulsions: gliadin, caseinate, and whey protein. Food Chem. 175, 249-257. doi: 10.1016/j.foodchem.2014.11.112

Queirós, A. S., and Lopes-da-Silva, J. A. (2017). Nonthermal gelation of whey proteins induced by organic acids. J. Appl. Polym. Sci. 134:45134. doi: $10.1002 /$ app.45134

Raikos, V., Campbell, L., and Euston, S. R. (2007). Rheology and texture of hen's egg protein heat-set gels as affected by $\mathrm{pH}$ and the addition of sugar and/or salt. Food Hydrocolloids 21, 237-244. doi: 10.1016/j.foodhyd.2006.03.015

Ramos, Ó. L., Fernandes, J. C., Silva, S. I., Pintado, M. E., and Malcata, F. X. (2012). Edible films and coatings from whey proteins: a review on formulation, and on mechanical and bioactive properties. Crit. Rev. Food Sci. Nutr. 52, 533-552. doi: 10.1080/10408398.2010.500528

Remondetto, G. E., Beyssac, E., and Subirade, M. (2004). Iron availability from whey protein hydrogels: an in vitro study. J. Agric. Food Chem. 52, 8137-8143. doi: 10.1021/jf040286h

Renkema, J. M. S., Knabben, J. H. M., and Van Vliet, T. (2001). Gel formation by $\beta$-conglycinin and glycinin and their mixtures. Food Hydrocolloids 15, 407-414. doi: 10.1016/S0268-005X(01)00051-0

Rhim, J.-W., Lee, J. H., and Ng, P. K. W. (2007). Mechanical and barrier properties of biodegradable soy protein isolate-based films coated with polylactic acid. LWT Food Sci. Technol. 40, 232-238. doi: 10.1016/j.lwt.2005.10.002

Rubio-Aliaga, I., and Daniel, H. (2002). Mammalian peptide transporters as targets for drug delivery. Trends Pharmacol. Sci. 23, 434-440. doi: 10.1016/S0165-6147(02)02072-2

Sadeghi, S., Madadlou, A., and Yarmand, M. (2014). Microemulsification-cold gelation of whey proteins for nanoencapsulation of date palm pit extract. Food Hydrocolloids 35, 590-596. doi: 10.1016/j.foodhyd.2013.07.021

Sağlam, D., Venema, P., van der Linden, E., and de Vries, R. (2014). Design, properties, and applications of protein micro- and nanoparticles. Curr. Opin. Colloid Interface Sci. 19, 428-437. doi: 10.1016/j.cocis.2014.09.004 
Saha, D., and Bhattacharya, S. (2010). Hydrocolloids as thickening and gelling agents in food: a critical review. J. Food Sci. Technol. 47, 587-597. doi: 10.1007/s13197-010-0162-6

Saluja, A., and Kalonia, D. S. (2008). Nature and consequences of protein-protein interactions in high protein concentration solutions. Int. J. Pharm. 358, 1-15. doi: 10.1016/j.ijpharm.2008.03.041

Sava, N., Van der Plancken, I., Claeys, W., and Hendrickx, M. (2005). The kinetics of heat-induced structural changes of $\beta$-lactoglobulin. J. Dairy Sci. 88, 1646-1653. doi: 10.3168/jds.S0022-0302(05)72836-8

Schmid, M., Dallmann, K., Bugnicourt, E., Cordoni, D., Wild, F., Lazzeri, A., et al. (2012). Properties of whey-protein-coated films and laminates as novel recyclable food packaging materials with excellent barrier properties. Int. J. Polym. Sci. 2012:562381. doi: 10.1155/2012/562381

Sharif, H. R., Goff, H. D., Majeed, H., Liu, F., Nsor-Atindana, J., Haider, J., et al. (2017). Physicochemical stability of $\beta$-carotene and $\alpha$-tocopherol enriched nanoemulsions: influence of carrier oil, emulsifier and antioxidant. Colloids Surf. A 529, 550-559. doi: 10.1016/j.colsurfa.2017.05.076

Shpigelman, A., Cohen, Y., and Livney, Y. D. (2012). Thermally-induced $\beta$ lactoglobulin-EGCG nanovehicles: loading, stability, sensory and digestiverelease study. Food Hydrocolloids 29, 57-67. doi: 10.1016/j.foodhyd.2012.01.016

Sneharani, A. H., Karakkat, J. V., Singh, S. A., and Rao, A. G. A. (2010). Interaction of curcumin with $\beta$-lactoglobulin-stability, spectroscopic analysis, and molecular modeling of the complex. J. Agric. Food Chem. 58, 11130-11139. doi: $10.1021 /$ jf102826q

Sobral, P. J. A., Menegalli, F. C., Hubinger, M. D., and Roques, M. A. (2001). Mechanical, water vapor barrier and thermal properties of gelatin based edible films. Food Hydrocolloids 15, 423-432. doi: 10.1016/S0268-005X(01)0 0061-3

Song, M., Fung, T. T., Hu, F. B., Willett, W. C., Longo, V. D., Chan, A. T., et al. (2016). Association of animal and plant protein intake with allcause and cause-specific mortality. JAMA Intern. Med. 176, 1453-1463. doi: 10.1001/jamainternmed.2016.4182

Speroni, F., Beaumal, V., de Lamballerie, M., Anton, M., Añón, M. C., and Puppo, M. C. (2009). Gelation of soybean proteins induced by sequential high-pressure and thermal treatments. Food Hydrocolloids 23, 1433-1442. doi: 10.1016/.j.foodhyd.2008.11.008

Speroni, F., Jung, S., and De Lamballerie, M. (2010). Effects of calcium and pressure treatment on thermal gelation of soybean protein. J. Food Sci. 75, E30-E38. doi: 10.1111/j.1750-3841.2009.01390.x

Sponton, O. E., Perez, A. A., Carrara, C. R., and Santiago, L. G. (2015). Linoleic acid binding properties of ovalbumin nanoparticles. Colloids Surf. B 128, 219-226. doi: 10.1016/j.colsurfb.2015.01.037

Sponton, O. E., Perez, A. A., Ramel, J. V., and Santiago, L. G. (2017). Protein nanovehicles produced from egg white. Part 1: effect of $\mathrm{pH}$ and heat treatment time on particle size and binding capacity. Food Hydrocolloids 73, 67-73. doi: 10.1016/j.foodhyd.2017.06.033

Sponton, O. E., Perez, A. A., Ramel, J. V., and Santiago, L. G. (2018). Protein nanovehicles produced from egg white. Part 2: effect of protein concentration and spray drying on particle size and linoleic acid binding capacity. Food Hydrocolloids 77, 863-869. doi: 10.1016/j.foodhyd.2017.11.030

Spotti, M. J., Tarhan, Ö., Schaffter, S., Corvalan, C., and Campanella, O. H. (2017). Whey protein gelation induced by enzymatic hydrolysis and heat treatment: comparison of creep and recovery behavior. Food Hydrocolloids 63, 696-704. doi: 10.1016/j.foodhyd.2016.10.014

Steffe, J. F. (1996). Rheological Methods in Food Process Engineering. East Lansing, MI: Freeman Press.

Stokes, J. R. (2011). "Rheology of industrially relevant microgels," in Microgel Suspensions, eds A. Fernandez-Nieves, H. Wyss, J. Mattsson, and D. A. Weitz (Weinheim: Wiley-VCH Verlag GmbH \& Co. KGaA), 327-353.

Suárez, A., Fernández, L., Balbarie, P., Iglesias, J. R. N., and Riera, F. A. (2016). Predicting the properties of the whey protein microparticles produced by heat and mechanical treatments. Eur. Food Res. Technol. 242, 1211-1220. doi: $10.1007 / \mathrm{s} 00217-015-2625-5$

Suktham, K., Koobkokkruad, T., Wutikhun, T., and Surassmo, S. (2018). Efficiency of resveratrol-loaded sericin nanoparticles: promising bionanocarriers for drug delivery. Int. J. Pharm. 537, 48-56. doi: 10.1016/j.ijpharm.2017.12.015
Sun, H., Luo, Q., Hou, C., and Liu, J. (2017). Nanostructures based on protein selfassembly: from hierarchical construction to bioinspired materials. Nano Today 14, 16-41. doi: 10.1016/j.nantod.2017.04.006

Sun, Y., and Hayakawa, S. (2002). Heat-induced gels of egg white/ovalbumins from five avian species: thermal aggregation, molecular forces involved, and rheological properties. J. Agric. Food Chem. 50, 1636-1642. doi: 10.1021/jf0109975

Sundar, S., Kundu, J., and Kundu, S. C. (2010). Biopolymeric nanoparticles. Sci. Technol. Adv. Mater. 11:014104. doi: 10.1088/1468-6996/11/1/014104

Tan, J. P. K., Wang, Q., and Tam, K. C. (2008). Control of burst release from nanogels via layer by layer assembly. J. Controll. Release 128, 248-254. doi: 10.1016/j.jconrel.2008.03.012

Tarhini, M., Greige-Gerges, H., and Elaissari, A. (2017). Protein-based nanoparticles: from preparation to encapsulation of active molecules. Int. J. Pharm. 522, 172-197. doi: 10.1016/j.ijpharm.2017.01.067

Tarone, A. G., Fasolin, L. H., Perrechil, F. D. A., Hubinger, M. D., and Cunha, R. L. D. (2013). Influence of drying conditions on the gelling properties of the 7S and 11S soy protein fractions. Food Bioprod. Process. 91, 111-120. doi: 10.1016/j.fbp.2012.11.010

Tárrega, A., and Costell, E. (2007). Colour and consistency of semi-solid dairy desserts: instrumental and sensory measurements. J. Food Eng. 78, 655-661. doi: 10.1016/j.jfoodeng.2005.11.003

Teng, Z., Luo, Y., Wang, T., Zhang, B., and Wang, Q. (2013). Development and application of nanoparticles synthesized with folic acid conjugated soy protein. J. Agric. Food Chem. 61, 2556-2564. doi: 10.1021/jf4001567

Teo, A., Lee, S. J., Goh, K. K. T., and Wolber, F. M. (2017). Kinetic stability and cellular uptake of lutein in WPI-stabilised nanoemulsions and emulsions prepared by emulsification and solvent evaporation method. Food Chem. 221, 1269-1276. doi: 10.1016/j.foodchem.2016.11.030

Torres, I. C., Janhøj, T., Mikkelsen, B. Ø., and Ipsen, R. (2011). Effect of microparticulated whey protein with varying content of denatured protein on the rheological and sensory characteristics of low-fat yoghurt. Int. Dairy J. 21, 645-655. doi: 10.1016/j.idairyj.2010.12.013

Verheul, M., and Roefs, S. P. F. M. (1998). Structure of particulate whey protein gels: effect of $\mathrm{NaCl}$ concentration, $\mathrm{pH}$, heating temperature, and protein composition. J. Agric. Food Chem. 46, 4909-4916. doi: 10.1021/jf981100f

Vermonden, T., Censi, R., and Hennink, W. E. (2012). Hydrogels for protein delivery. Chem. Rev. 112, 2853-2888. doi: 10.1021/cr200157d

Waku, T., Kanamaru, K., Hiroyama, Y., Sasaki, R., Morimoto, N., and Tanaka, N. (2018). Preparation of nanoparticles composed of egg white protein and their application for cell adhesion control. Kobunshi Ronbunshu 75, 61-68. doi: 10.1295/koron.2017-0070

Wang, C. S., Virgilio, N., Wood-Adams, P., and Heuzey, M. C. (2017). A mechanism for the synergistic gelation properties of gelatin $B$ and xanthan gum aqueous mixtures. Carbohydr. Polym. 175, 484-492. doi: 10.1016/j.carbpol.2017.08.015

Wang, R., Tian, Z., and Chen, L. (2011). Nano-encapsulations liberated from barley protein microparticles for oral delivery of bioactive compounds. Int. J. Pharm. 406, 153-162. doi: 10.1016/j.ijpharm.2010.12.039

Weijers, M., Van De Velde, F., Stijnman, A., Van De Pijpekamp, A., and Visschers, R. W. (2006). Structure and rheological properties of acid-induced egg white protein gels. Food Hydrocolloids 20, 146-159. doi: 10.1016/j.foodhyd.2005.02.013

Wijaya, W., Van der Meeren, P., and Patel, A. R. (2017). Cold-set gelation of whey protein isolate and low-methoxyl pectin at low pH. Food Hydrocolloids 65, 35-45. doi: 10.1016/j.foodhyd.2016.10.037

Wong, D. W. S., Camirand, W. M., Pavlath, A. E., Parris, N., and Friedman, M. (1996). Structures and functionalities of milk proteins*. Crit. Rev. Food Sci. Nutr. 36, 807-844. doi: 10.1080/10408399609527751

Wu, J., Shi, M., Li, W., Zhao, L., Wang, Z., Yan, X., et al. (2015). Pickering emulsions stabilized by whey protein nanoparticles prepared by thermal crosslinking. Colloids Surf. B 127, 96-104. doi: 10.1016/j.colsurfb.2015.01.029

Wu, P., Dhital, S., Williams, B. A., Chen, X. D., and Gidley, M. J. (2016). Rheological and microstructural properties of porcine gastric digesta and diets containing pectin or mango powder. Carbohydr. Polym. 148, 216-226. doi: 10.1016/j.carbpol.2016.04.037 
Xu, M., Gagné-Bourque, F., Dumont, M.-J., and Jabaji, S. (2016). Encapsulation of Lactobacillus casei ATCC 393 cells and evaluation of their survival after freezedrying, storage and under gastrointestinal conditions. J. Food Eng. 168, 52-59. doi: $10.1016 /$ j.jfoodeng.2015.07.021

Yang, J., Zhou, Y., and Chen, L. (2014). Elaboration and characterization of barley protein nanoparticles as an oral delivery system for lipophilic bioactive compounds. Food Funct. 5, 92-101. doi: 10.1039/C3FO60351B

Yang, N., Lv, R., Jia, J., Nishinari, K., and Fang, Y. (2017). Application of microrheology in food science. Annu. Rev. Food Sci. Technol. 8, 493-521. doi: 10.1146/annurev-food-030216-025859

Yang, S., Dai, L., Sun, C., and Gao, Y. (2018). Characterization of curcumin loaded gliadin-lecithin composite nanoparticles fabricated by antisolvent precipitation in different blending sequences. Food Hydrocolloids 85, 185-194. doi: 10.1016/j.foodhyd.2018.07.015

Yi, J., Lam, T. I., Yokoyama, W., Cheng, L. W., and Zhong, F. (2015). Beta-carotene encapsulated in food protein nanoparticles reduces peroxyl radical oxidation in Caco-2 cells. Food Hydrocolloids 43, 31-40. doi: 10.1016/j.foodhyd.2014.04.028

Ying, D. Y., Schwander, S., Weerakkody, R., Sanguansri, L., Gantenbein-Demarchi, C., and Augustin, M. A. (2013). Microencapsulated Lactobacillus rhamnosus GG in whey protein and resistant starch matrices: probiotic survival in fruit juice. J. Funct. Foods 5, 98-105. doi: 10.1016/j.jff.2012.08.009

Zand-Rajabi, H., and Madadlou, A. (2016a). Caffeine-loaded whey protein hydrogels reinforced with gellan and enriched with calcium chloride. Int. Dairy J. 56, 38-44. doi: 10.1016/j.idairyj.2015.12.011

Zand-Rajabi, H., and Madadlou, A. (2016b). Citric acid cross-linking of heat-set whey protein hydrogel influences its textural attributes and caffeine uptake and release behaviour. Int. Dairy J. 61, 142-147. doi: 10.1016/j.idairyj.2016.05.008

Zhang, J., Field, C. J., Vine, D., and Chen, L. (2014). Intestinal uptake and transport of vitamin B12-loaded soy protein nanoparticles. Pharm. Res. 32, 1288-1303. doi: $10.1007 / \mathrm{s} 11095-014-1533-\mathrm{x}$

Zhang, J., Liang, L., Tian, Z., Chen, L., and Subirade, M. (2012). Preparation and in vitro evaluation of calcium-induced soy protein isolate nanoparticles and their formation mechanism study. Food Chem. 133, 390-399. doi: 10.1016/j.foodchem.2012.01.049

Zhang, X., Do, M. D., Dean, K., Hoobin, P., and Burgar, I. M. (2007). Wheatgluten-based natural polymer nanoparticle composites. Biomacromolecules 8 , 345-353. doi: $10.1021 / \mathrm{bm} 060929 \mathrm{x}$

Zhang, Y., Cui, L., Che, X., Zhang, H., Shi, N., Li, C., et al. (2015). Zein-based films and their usage for controlled delivery: origin, classes and current landscape. $J$. Controll. Release 206, 206-219. doi: 10.1016/j.jconrel.2015.03.030
Zhang, Z., Zhang, R., Chen, L., Tong, Q., and McClements, D. J. (2015) Designing hydrogel particles for controlled or targeted release of lipophilic bioactive agents in the gastrointestinal tract. Eur. Polym. J. 72, 698-716. doi: 10.1016/j.eurpolymj.2015.01.013

Zhang, Z.-H., Wang, X.-P., Ayman, W. Y., Munyendo, W. L. L., Lv, H.-X., and Zhou, J.-P. (2013). Studies on lactoferrin nanoparticles of gambogic acid for oral delivery. Drug Deliv. 20, 86-93. doi: 10.3109/10717544.2013. 766781

Zhong, S., Cui, X., and Tian, F. (2015). Fabrication of redox-responsive magnetic protein microcapsules from hen egg white by the sonochemical method. J. Microencapsul. 32, 705-710. doi: 10.3109/02652048.2015.10 73389

Zhu, X. F., Zhang, N., Lin, W. F., and Tang, C. H. (2017). Freezethaw stability of pickering emulsions stabilized by soy and whey protein particles. Food Hydrocolloids 69, 173-184. doi: 10.1016/j.foodhyd.2017. 02.001

Zimet, P., and Livney, Y. D. (2009). Beta-lactoglobulin and its nanocomplexes with pectin as vehicles for $\omega-3$ polyunsaturated fatty acids. Food Hydrocolloids 23 , 1120-1126. doi: 10.1016/j.foodhyd.2008.10.008

Zou, L., Zheng, B., Zhang, R., Zhang, Z., Liu, W., Liu, C., et al. (2016) Enhancing the bioaccessibility of hydrophobic bioactive agents using mixed colloidal dispersions: curcumin-loaded zein nanoparticles plus digestible lipid nanoparticles. Food Res. Int. 81, 74-82. doi: 10.1016/j.foodres.2015. 12.035

Zuidam, N. J., and Shimoni, E. (2010). "Overview of microencapsulates for use in food products or processes and methods to make them," in Encapsulation Technologies for Active Food Ingredients and Food Processing, eds N. J. Zuidam and V. Nedovic (New York, NY: Springer), 3-29.

Conflict of Interest Statement: The authors declare that the research was conducted in the absence of any commercial or financial relationships that could be construed as a potential conflict of interest.

Copyright () 2018 Martins, Bourbon, Pinheiro, Fasolin and Vicente. This is an openaccess article distributed under the terms of the Creative Commons Attribution License (CC BY). The use, distribution or reproduction in other forums is permitted, provided the original author $(s)$ and the copyright owner(s) are credited and that the original publication in this journal is cited, in accordance with accepted academic practice. No use, distribution or reproduction is permitted which does not comply with these terms. 